\title{
Tracing the transport of colored dissolved organic matter in water masses of the Southern Beaufort Sea: relationship with hydrographic characteristics
}

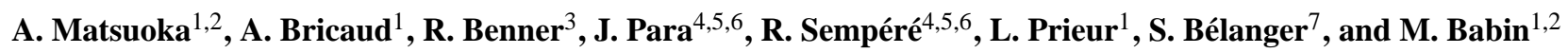 \\ ${ }^{1}$ Laboratoire d'Océanographie de Villefranche, UMR 7093, Université Pierre et Marie Curie (Paris 6)/Centre National de la \\ Recherche Scientifique (CNRS), B.P. 08, Port de la Darse, Villefranche-sur-Mer Cedex, 06230, France \\ ${ }^{2}$ Takuvik Joint International Laboratory, Université Laval (Canada) - CNRS (France), Département de Biologie \\ and Québec-Océan, Université Laval, Pavillon Alexandre-Vachon 1045, avenue de la Médecine, Local 2078, G1V 0A6, \\ Canada \\ ${ }^{3}$ Department of Biological Sciences, University of South Carolina, Columbia, SC 29208, USA \\ ${ }^{4}$ Aix-Marseille University, Mediterranean Institute of Oceanography (MIO), 13288, Marseille, Cedex 09, France \\ ${ }^{5}$ Université du Sud Toulon-Var, MIO, 83957, La Garde Cedex, France \\ ${ }^{6}$ CNRS/INSU, MIO UMR 7294; IRD, MIO UMR 235, France \\ ${ }^{7}$ Université du Québec à Rimouski, Département de Biologie, Chimie et Géographie, 300 allée des Ursulines, Rimouski, \\ Québec, G5L 3A1, Canada
}

Correspondence to: A. Matsuoka (atsushi.matsuoka@obs-vlfr.fr)

Received: 27 October 2011 - Published in Biogeosciences Discuss.: 11 November 2011

Revised: 7 February 2012 - Accepted: 7 February 2012 - Published: 6 March 2012

\begin{abstract}
Light absorption by colored dissolved organic matter $(\mathrm{CDOM})[\operatorname{acDOM}(\lambda)]$ plays an important role in the heat budget of the Arctic Ocean, contributing to the recent decline in sea ice, as well as in biogeochemical processes. We investigated $\mathrm{a}_{\mathrm{CDOM}}(\lambda)$ in the Southern Beaufort Sea where a significant amount of CDOM is delivered by the Mackenzie River. In the surface layer, $\mathrm{a}_{\mathrm{CDOM}}(440)$ showed a strong and negative correlation with salinity, indicating strong river influence and conservative transport in the river plume. Below the mixed layer, a weak but positive correlation between $\mathrm{a}_{\mathrm{CDOM}}(440)$ and salinity was observed above the upper halocline, resulting from the effect of removal of CDOM due to brine rejection and lateral intrusion of Pacific summer waters into these layers. In contrast, the relationship was negative in the upper and the lower haloclines, suggesting these waters originated from Arctic coastal waters. DOC concentrations in the surface layer were strongly correlated with $\mathrm{a}_{\mathrm{CDOM}}(440)\left(r^{2}=0.97\right)$, suggesting that this value can be estimated in this area, using a ${ }_{\mathrm{CDOM}}(440)$ that is retrieved using satellite ocean color data. Implications for estimation of DOC concentrations in surface waters using ocean color remote sensing are discussed.
\end{abstract}

\section{Introduction}

The Southern Beaufort Sea (Fig. 1) is one of the regions where a significant reduction of sea ice cover has been recorded over the last three decades (Stroeve et al., 2008). In the south, the continental shelf receives a flow of freshwater from the Mackenzie River $\left(330 \mathrm{~km}^{3} \mathrm{yr}^{-1}\right.$ : Aagaard and Carmack, 1989). The freshwater includes a large amount of nutrients, suspended sediments, and dissolved organic matter (DOM) originating from soils that include thawing of the permafrost (Holmes et al., 2002; Carmack et al., 2004; Camill, 2005; Emmerton et al., 2008). A series of papers have suggested that the freshwater discharge into the Arctic rivers has increased since the middle of the 20th century (e.g., Peterson et al., 2002; McClelland et al., 2006). While the expected increase in nutrients delivered by rivers into the Arctic Ocean may enhance phytoplankton growth, both particulate and dissolved materials can reduce the light propagating into the water column, preventing phytoplankton from harvesting sufficient light for their growth. How the biogeochemical processes in the Arctic coastal region will respond to climate change is unclear. 


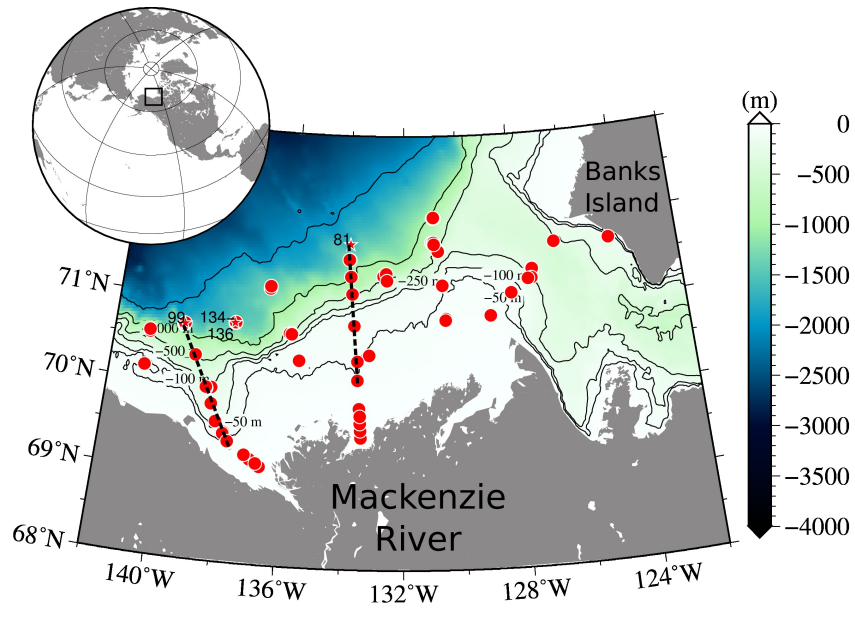

Fig. 1. Location of sampling stations for the MALINA cruise in the Southern Beaufort Sea, Canadian Arctic. Three deep stations (bottom depth $>1000 \mathrm{~m}$ ) were selected to show typical hydrography of the Arctic Ocean (stars). One profile at station 310 (cast \# 81) and 620 (cast \# 99) each and three profiles at station 540 (cast \# 134136) are shown in Fig. 3. Two black and dashed lines represent west and east channels of the Mackenzie river. Vertical sections along those lines are shown in Fig. 6 .

Light-absorbing colored DOM (CDOM) plays various roles in physical and biogeochemical processes in the Southern Beaufort Sea. As a physical role, light absorption of $\mathrm{CDOM}$ is likely responsible for a significant part of the heat storage of the upper layer of the Arctic Ocean (Hill, 2008), which amplified the recent decline in sea ice extent in this region (Shimada et al., 2006). This result is consistent with the fact that the relative contribution of this material to the total non-water light absorption is remarkably high in the Arctic Ocean $(66 \pm 17 \%$ at $440 \mathrm{~nm})$ throughout the ice-free seasons compared to that at lower latitudes (Matsuoka et al., 2011). With regard to biogeochemistry, exposure of CDOM in seawater to solar radiation at all latitudes produces inorganic carbon-based gases such as carbon dioxide $\left(\mathrm{CO}_{2}\right)$ and carbon monoxide $(\mathrm{CO})$, suggesting that this process may affect the organic carbon cycle in the Arctic Ocean (Xie and Gosselin, 2005; Bélanger et al., 2006; Xie et al., 2009). In addition, relatively refractory DOM can be transformed into a labile and biologically available DOM resulting from photodegradation processes (Miller and Zepp, 1995; Miller and Moran, 1997). The labile DOM can stimulate microbial activities and hence the biological pump (Miller et al., 2002).

$\mathrm{CDOM}$ is inversely correlated with salinity in estuaries, indicating a terrigenous source of CDOM in coastal waters. In contrast, there is a significant and positive correlation between this absorption and chlorophyll- $a$ (chl- $a$ ) concentration in oceanic waters, suggesting phytoplankton-derived components contribute to CDOM (e.g., Bricaud et al., 2010). In addition, the spectral slope of CDOM absorption can give insights about sources and the bulk chemical properties of
CDOM (Carder et al., 1989; Helms et al., 2008; Fichot and Benner, 2011), which are possibly influenced by photochemical and/or biological processes (e.g., Twardowski and Donaghay., 2002; Bricaud et al., 2010). Thus, CDOM absorption properties provide insights about source and physicochemical and biological processes.

In the Arctic Ocean, several sources of CDOM are considered. A significant amount of CDOM in the Arctic surface layer originates from land by river discharge (Bélanger et al., 2006; Retamal et al., 2007; Matsuoka et al., 2009). In the Polar Mixed Layer (PML), previous papers showed that DOM can be removed due to brine rejection (Amon, 2004; Dittmar, 2004), therefore a fraction of CDOM can also be removed due to brine rejection when sea ice is formed. Matsuoka et al. (2011) suggested that CDOM could be transported into the Pacific Summer Water (PSW) layer, which is located just below the PML, by the intrusion of waters from the Bering Sea during summer. In addition to photochemical and microbial processes, these findings suggest that CDOM variability is also related to physical processes, but relationships between CDOM absorption properties and hydrographic features are still not sufficiently understood in the Arctic Ocean.

The objective of this study is therefore to examine characteristics of CDOM absorption and its transport in the Southern Beaufort Sea using both optical and hydrographic datasets. The linkage between CDOM absorption and dissolved organic carbon (DOC) concentration is also examined at the end of this paper in view of ocean color remote sensing applications.

\section{Materials and methods}

The France-Canada-USA joint Arctic campaign, MALINA, was conducted in the Southern Beaufort Sea in the area from approximately latitudes $69^{\circ}$ to $72^{\circ} \mathrm{N}$ and longitudes $125^{\circ}$ to $145^{\circ} \mathrm{W}$ (Fig. 1). Data were collected from 30th July to 27th August 2009 aboard the Icebreaker CCGS Amundsen, and 37 stations were visited. Temperature and salinity profiles were obtained using a SBE-911 plus (SeaBird) conductivitytemperature-depth (CTD) probe. Nitrate and oxygen concentrations, chlorophyll fluorescence, and CDOM fluorescence were also obtained using MIBARI-ISUS (Satlantic), SBE43 (SeaBird), Seapoint (Seapoint), and Backscat 1 (Haadrt Optic and Mikroelectonic) sensors, respectively. All sensors were attached to the CTD probe. Discrete water samples were collected using CTD/Niskin bottles. A barge and/or zodiac were also deployed at 32 stations out of 37 stations during the same time periods of the CTD deployment to obtain surface water samples. Those deployments were conducted to collect samples close to the surface $(0-0.5 \mathrm{~m}$ using a clean plastic container), which are difficult to obtain using a CTD/Niskin ("Surface" waters using a CTD/Niskin are usually taken from 2 to $4 \mathrm{~m}$ depth depending on the sea state), and to minimize the effect of the contamination by 
the icebreaker. Differences in CDOM absorption of surface waters between samples from the CTD/Niskin and from the barge/zodiac are discussed in Appendix A1.

\subsection{CDOM absorption}

The detailed methodology to determine light absorbance of CDOM using an UltraPath (World Precision Instruments, Inc.) is documented in Bricaud et al. (2010). Briefly, a sample was collected from a CTD/Niskin bottle (or from a plastic container when using the barge or zodiac) into pre-rinsed glass bottles covered with aluminium foil. Those samples were filtered immediately after sampling, in dim light, using $0.2 \mu \mathrm{m}$ GHP filters (Acrodisc Inc.) pre-rinsed with $200 \mathrm{ml}$ of Milli-Q water. Filtered samples were then pumped into the sample cell of the Ultrapath instrument using a peristaltic pump. Absorbance spectra were measured from 200 to $735 \mathrm{~nm}$ with $1 \mathrm{~nm}$ increments with reference to a salt solution (the salinity of the reference was adjusted to that of the sample \pm 2 salinity unit), prepared with Milli-Q water and granular $\mathrm{NaCl}$ precombusted in an oven (at $450^{\circ} \mathrm{C}$ for $4 \mathrm{~h}$ ). The sample tube was cleaned between measurements with diluted solutions of detergent, high reagent grade $\mathrm{MeOH}, 0.1 \mathrm{~N}$ $\mathrm{HCl}$, and with Milli-Q water. The cleanliness of the tube was checked by measuring the absorption spectrum of the reference water between each sample.

Temperature differences between reference and sample were minimized as far as possible, but could not be always avoided. As absorbance of pure water depends on temperature, this sometimes resulted in an underestimate of absorbance mostly beyond $700 \mathrm{~nm}$ for some samples. No temperature correction was applied to absorbance spectra in the data. To minimize the temperature and salinity effects on the absorbance among samples, the averages of the measured values of $\operatorname{OD}_{\mathrm{CDOM}}(\lambda)$ over a $5-\mathrm{nm}$ interval around $685 \mathrm{~nm}$ $\left(\mathrm{OD}_{\text {null, }} \mathrm{CDOM}\right)$ was assumed to be 0 and the $\operatorname{OD}_{\mathrm{CDOM}}(\lambda)$ spectrum was shifted accordingly (Pegau et al., 1997; Babin et al., 2003):

$a_{\mathrm{CDOM}}(\lambda)=2.303 \frac{\left[\mathrm{OD}_{\mathrm{CDOM}}(\lambda)-\mathrm{OD}_{\text {null, } \mathrm{CDOM}}\right]}{l}$,

where 2.303 is a factor for converting base e to base $10 \log$ arithms, and $l$ is the optical pathlength (m). In most cases, a $2 \mathrm{~m}$ optical pathlength was used for the measurement, except for coastal waters at the Mackenzie River mouth where a $0.1 \mathrm{~m}$ optical pathlength was used. The presence of microbubbles in the sample tube was minimized by using a peristaltic pump. When not totally removed, microbubbles induced a significant (and artificial) absorption detectable in the infrared, and the corresponding absorption spectra were discarded.

Spectra of $\mathrm{a}_{\mathrm{CDOM}}(\lambda)$ can be expressed as exponential functions as follows (e.g., Bricaud et al., 1981; Babin et al., 2003):

$a_{\mathrm{CDOM}}(\lambda)=a_{\mathrm{CDOM}}\left(\lambda_{r}\right) e^{\left(-S_{\mathrm{CDOM}}\left(\lambda-\lambda_{r}\right)\right)}$,

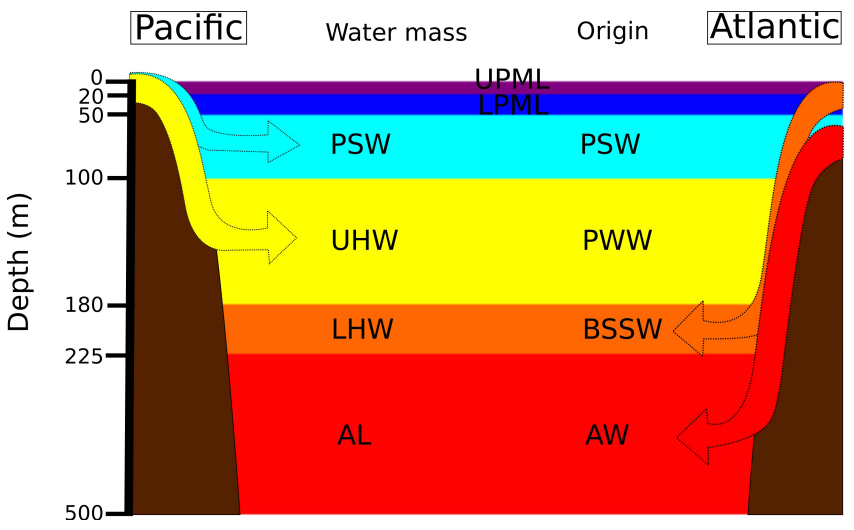

Fig. 2. A schematic image of water masses of the Arctic Ocean. The different water masses correspond to different colors as in Figs. 5 and 7-10.

where $\lambda_{r}$ is a reference wavelength ( $440 \mathrm{~nm}$ in this study), and $S_{\mathrm{CDOM}}$ denotes the spectral slope of CDOM. $S_{\mathrm{CDOM}}$ was calculated by fitting a non-linear regression to the data from 350 to $500 \mathrm{~nm}$ (Babin et al., 2003). In total, 373 samples were collected for CDOM absorption analyses at 37 stations.

\subsection{DOC determination}

Dissolved organic carbon (DOC) was measured using the high-temperature combustion method and either a TOC-V or TOC-5000 analyzer (Shimadzu) (Benner and Strom, 1993; Sohrin and Sempéré, 2005). Filtered water samples were stored frozen until analysis in laboratory. In total, 256 samples were collected for DOC analyses at 29 stations.

\section{Background: Hydrography of the Arctic Ocean}

Because we examined CDOM absorption properties for each water mass present in the Southern Beaufort Sea, the major hydrographical features are presented first and discussed. The vertical structure of the Arctic Ocean is unique and determined by river discharge/ice melt, vertical mixing, and lateral intrusion of both Pacific and Atlantic waters (e.g., Coachman and Aagaard, 1975; Aagaard, 1989; see Fig. 2). The surface layer can be separated into two water masses: the upper (UPML) and lower (LPML) parts of the PML. The UPML includes Mackenzie river water and/or sea ice melt water in summer and is characterized by relatively fresh water (salinity <28). It is typically found from the surface to $20 \mathrm{~m}$ (Macdonald et al., 1989). Below the UPML, the LPML is found from 20 to $50 \mathrm{~m}$ and is characterized by a temperature minimum around a salinity of 30.5 . The temperature minimum indicates that waters from the previous winter stay at those depths (Carmack et al., 1989; Macdonald et al., 1989). Below the LPML, Pacific summer waters (PSW; salinity centered at 31.5) from the Bering Sea enter 

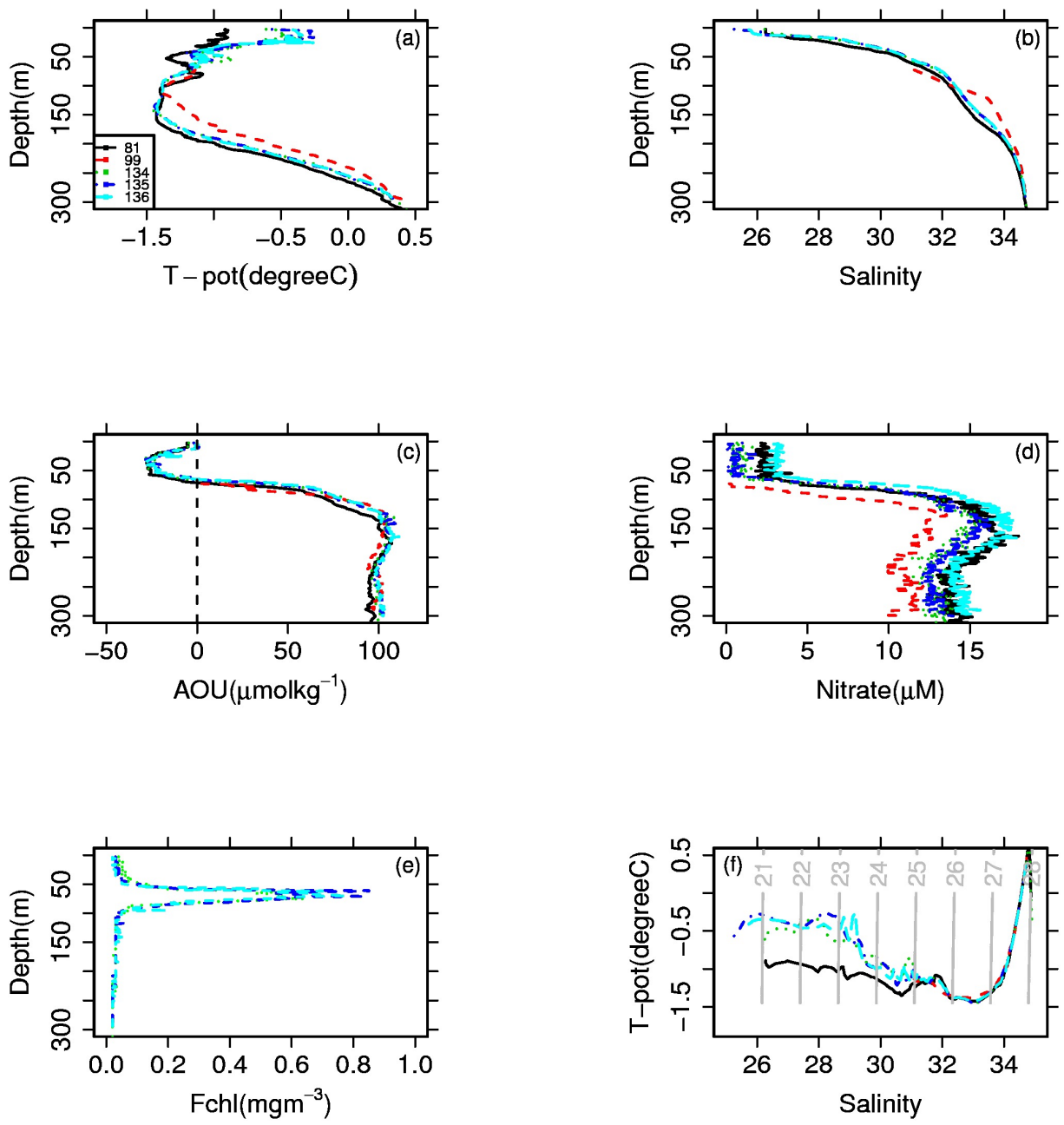

Fig. 3. Observed hydrography of the Arctic Ocean during the MALINA cruise. (a) Potential temperature (in $\left.{ }^{\circ} \mathrm{C}\right)$, (b) Salinity, (c) Apparent dissolved oxygen utilization (AOU) concentration (in $\mu \mathrm{mol} \mathrm{kg}^{-1}$ ), (d) Nitrate concentration (in $\mu \mathrm{M}$ ), (e) chlorophyll fluorescence, $\mathrm{F}_{\text {chl }}$ (in $\mathrm{mg} \mathrm{m}^{-3}$ ), and (f) $T-S$ diagram. These profiles were obtained at deep stations (bottom depth $>1000 \mathrm{~m}$; see Fig. 1 for location) as representatives of typical hydrography of the Western Arctic Ocean. $\mathrm{F}_{\mathrm{chl}}$ at stations 81 and 99 were not obtained.

the Chukchi Sea during summer, and are then located from approximately $50 \mathrm{~m}$ to $100 \mathrm{~m}$ depth (Carmack et al., 1989; Macdonald et al., 1989; Shimada et al., 2001). This water is characterized by a temperature maximum around the centered salinity (Shimada et al., 2001). Below the PSW, Pacific winter waters (PWW: salinity centered at 33.1) form upper halocline waters (UHW) from $100 \mathrm{~m}$ to $180 \mathrm{~m}$ depth (Carmack et al., 1989; Macdonald et al., 1989; Shimada et al., 2005). This water mass has a temperature minimum $\left(\approx-1.4^{\circ} \mathrm{C}\right)$ and clear maxima of nitrate and silicate concentrations (Codispoti et al., 2005; Shimada et al., 2005). The lower halocline water (LHW) located around 180 to $225 \mathrm{~m}$ originates from the Barents Sea shelf water (BSSW; Eastern Arctic) when sea ice is formed (e.g., Shauer et al., 1997). This water has salinities ranging from 33.9 to 34.7 , and is characterized by relatively high oxygen concentrations compared to that in the layers above (Shimada et al., 2005). Atlantic-origin waters (AW) with salinities $>34.7$ are warmer $\left(>0{ }^{\circ} \mathrm{C}\right)$ and form the Atlantic layer (AL) located from $225 \mathrm{~m}$ to $800 \mathrm{~m}$ (Shauer et al., 1997; Shimada et al., 2005). Below those layers, cold and dense Arctic bottom waters (ABW) are present (e.g., Aagaard, 1989).

Based on the physical properties of the water masses (Carmack et al., 1989; Macdonald et al., 1989; Shimada et al., 2001, 2005) and two chemical variables, nitrate and oxygen concentrations (Codispoti et al., 2005; Shimada et al., 2005), we grouped water masses into 6 categories (see Table 1).

UPML (1) was defined as waters $<20 \mathrm{~m}$ and salinity $<28$. During our observations, temperatures in the UPML ranged from -1.0 to $-0.2{ }^{\circ} \mathrm{C}$ and salinities were low (salinity $<28$; Fig. 3a and b). This layer was influenced by sea ice melt and/or river discharge. LPML (2) had salinities ranging from 28 to 30.7. A minimum of apparent oxygen utilization (AOU) was observed from 20 to $50 \mathrm{~m}$ depth where salinity increased sharply (Fig. 3c). It appears that the net production of oxygen by photosynthesis in these waters led to the 
Table 1. Definition of water masses in this study.

\begin{tabular}{llll}
\hline Water mass & Depth $(\mathrm{m})$ & Origin & Definition \\
\hline UPML & $<20$ & River discharge, melting sea ice, or both & Salinity $<28$ \\
LPML & $20-50$ & Arctic-origin Water & $28 \leq$ Salinity $<30.7$ \\
PSW & $50-100$ & Pacific Summer Water & $30.7 \leq$ Salinity $<32.3$ \\
PWW/UHW & $100-180$ & Pacific Winter Water & $32.3 \leq$ Salinity $<33.9$ \\
LHW & $180-225$ & Barents Sea Shelf Water & $33.9 \leq$ Salinity $<34.7$ \\
AL & $>225$ & Atlantic Water & Salinity $\geq 34.7$ \\
\hline
\end{tabular}

trapping of oxygen in the pycnocline, which prevented outgasing to the atmosphere. Solar heating can also change the saturation of oxygen and induce a negative AOU. The negative values of AOU are thus explained by either production of oxygen by phytoplankton, solar heating of winter mixed water, or both. Assuming temperature and salinity from the previous winter of $-1.8^{\circ} \mathrm{C}$ and 31 , respectively, we obtained AOU value of $-24 \pm 2\left(\mu \mathrm{mol} \mathrm{kg}{ }^{-1}\right)$. This value was higher than the observed value (i.e., $-30 \pm 2 \mu \mathrm{mol} \mathrm{kg}^{-1}$ ). The difference between those two values suggests that production of oxygen by phytoplankton explained on average $20 \%$ of the negative AOU value in this water mass. Solar heating was thus more important compared to production by phytoplankton for the negative AOU in relatively clear waters. A peak of chlorophyll fluorescence was observed around $70 \mathrm{~m}$ (Fig. 3e). This peak contributed to production of oxygen at those depths since AOU values were relatively low, but not as much as in LPML (Fig. 3c).

PSW (3) had salinity ranging from 30.7 to 32.3 . A small but clear temperature maximum centered around salinity 31.5 was found from approximately 50 to $100 \mathrm{~m}$ (Fig. 3a, b, and f), suggesting the presence of the PSW (Carmack et al., 1989; Shimada et al., 2001). PWW/UHW (4) had a salinity ranging from 32.3 to 33.9. The thick and cold halocline water had a broad temperature minimum from 100 to $180 \mathrm{~m}$ (Fig. 3a, b, and f). The clear maximum of nitrate concentration in this layer (Fig. 3d) was centered at salinity 33.1, which indicates this water mass was formed in the Western Arctic Ocean during winter (Codispoti et al., 2005; Shimada et al., 2005). LHW (5) had a salinity ranging from 33.9 to 34.7 and was found from 180 to $225 \mathrm{~m}$. Water temperatures increased strongly with depth in this salinity range, and oxygen concentrations were higher than in the layer above (not shown; Shimada et al., 2005). Those results suggest the presence of the LHW (Shauer et al., 1998; Shimada et al., 2005) that originates in the BSSW (Eastern Arctic). AL (6) had salinities $>34.7$ and temperatures $>0{ }^{\circ} \mathrm{C}$ (Fig. 3a). The relatively high temperature and salinity $(>34.7)$ indicated an intrusion of AW.

Water samples were obtained at CTD casts above $500 \mathrm{~m}$ depth. The percentages of total samples collected in each water mass were $20 \%$ (UPML), $22 \%$ (LPML), $41 \%$ (PSW), $11 \%$ (PWW/UHW), $4 \%$ (LHW), and 2\% (AL).
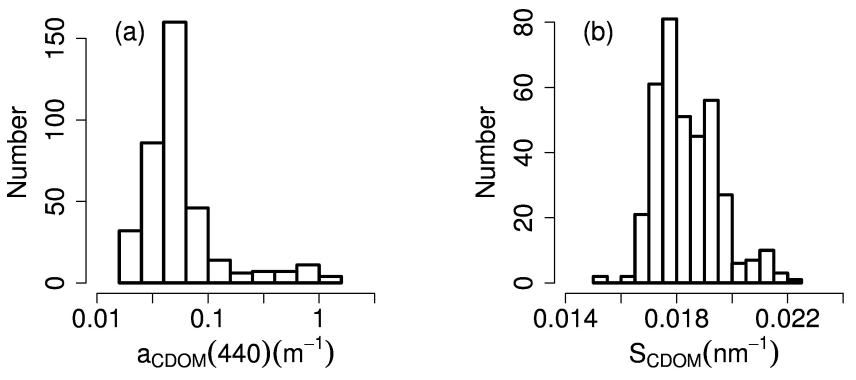

Fig. 4. Histograms of (a) the absorption coefficients of CDOM at $440 \mathrm{~nm}, \mathrm{a}_{\mathrm{CDOM}}(440)$ and (b) the spectral slope, $S_{\mathrm{CDOM}}$.

\section{Results}

\subsection{Variability in CDOM absorption properties and their relationships with hydrography}

Values of $\mathrm{a}_{\mathrm{CDOM}}(440)$ varied widely in Southern Beaufort Sea waters $\left(0.018 \mathrm{~m}^{-1}<\mathrm{a}_{\mathrm{CDOM}}(440)<1.08 \mathrm{~m}^{-1}\right.$; Fig. $\left.4 \mathrm{a}\right)$. Those values mostly fell within the range observed in both the western part of the Southern Beaufort Sea (Matsuoka et al., 2011) and various coastal waters at moderate latitudes (Kirk, 1994; Vodacek et al., 1997; Babin et al., 2003), with some high $\mathrm{a}_{\mathrm{CDOM}}(440)$ values (up to $1.08 \mathrm{~m}^{-1}$ ) which were observed near the mouth of the Mackenzie River. Values of the spectral slope of CDOM absorption, $S_{\mathrm{CDOM}}$, fell within a narrower range $\left(0.015 \mathrm{~nm}^{-1}<S_{\mathrm{CDOM}}(440)<0.023 \mathrm{~nm}^{-1}\right.$; Fig. 4b) compared to the western part of the Southern Beaufort Sea (Matsuoka et al., 2011), but were similar to values in coastal waters around Europe (Babin et al., 2003).

At salinity $<28$ (in the UPML), $\mathrm{a}_{\mathrm{CDOM}}(440)$ values showed a strong and negative correlation with salinity $\left(r^{2}=\right.$ $0.95, p<0.0001)$ except for some stations where waters were influenced by sea ice melt (dotted circle in Fig. 5a; $21 \%$ of our samples in the UPML). This negative correlation was observed previously in the same study area during summer (Bélanger et al., 2006) and elsewhere in coastal zones at lower latitudes (see Nieke et al., 1997 and references therein). During MALINA, the river plume extended farther offshore in the western channel than in the eastern channel, which was reflected in the spatial distribution of high CDOM absorption in the UPML (Fig. 6). 

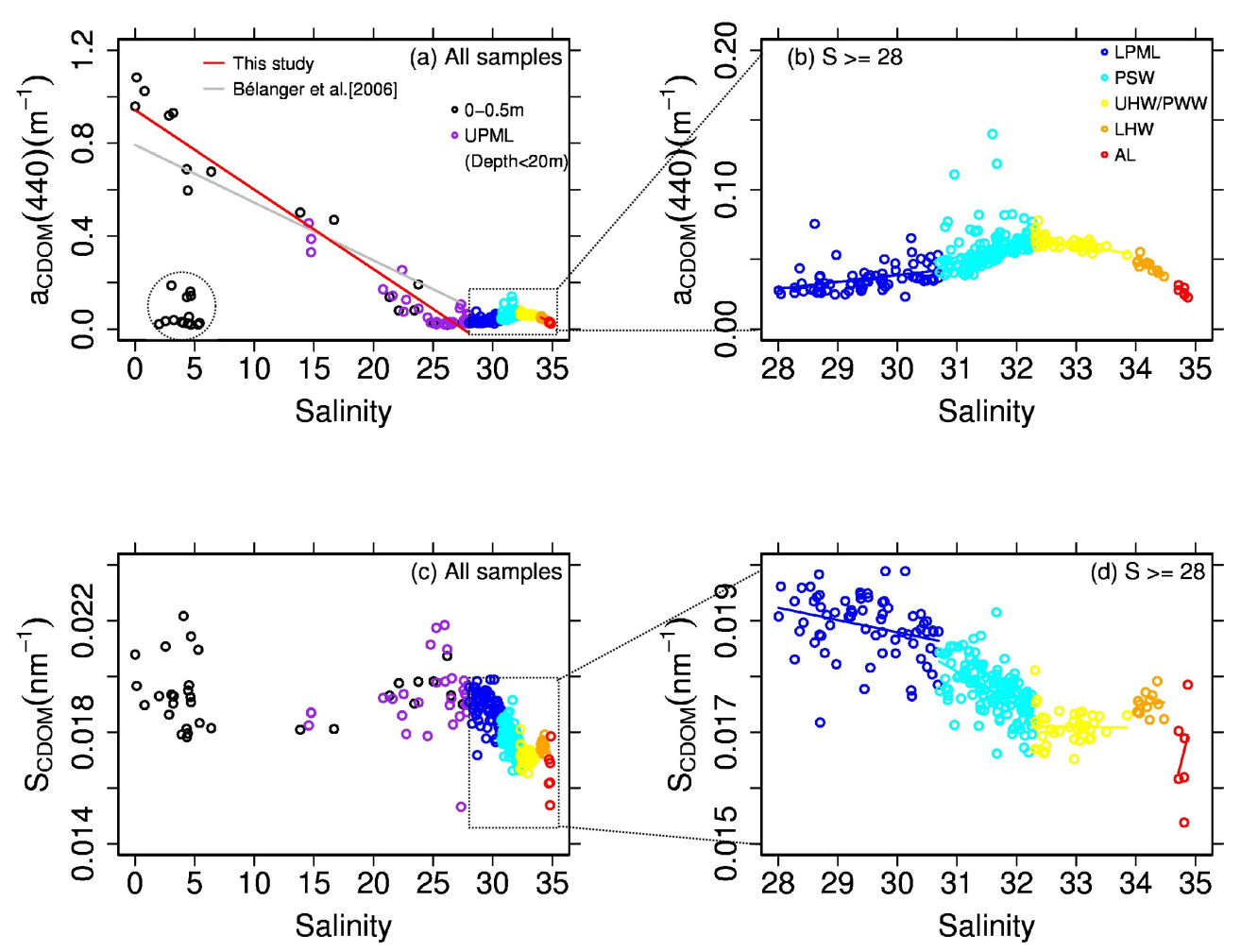

Fig. 5. Upper panels: $\operatorname{a}_{\mathrm{CDOM}}(440)$ as a function of salinity $(S)$ for (a) the whole range and (b) $S \geq 28$ (below the UPML). A linear fit provides the following relationship: $\mathrm{a}_{\mathrm{CDOM}}(440)=0.943-0.034 * \mathrm{~S}, N=52 ; p<0.0001$. Data points which were influenced by sea ice melt are marked as a dotted circle. Lower panels: $S_{\mathrm{CDOM}}$ as a function of $S$ for (c) whole range and (d) $S \geq 28$ (below the UPML).

For the LPML, a positive correlation with salinity $\left(r^{2}=0.14, p<0.001\right.$; dark blue points in Fig. 5b). Among the lowest $\mathrm{a}_{\mathrm{CDOM}}(440)$ values $\left(0.036 \pm 0.010\right.$ S.D. $\left.\mathrm{m}^{-1}\right)$ were observed in the low salinity range of this layer (i.e., $28 \leq$ salinity $<30.7$ ). The low $\mathrm{a}_{\mathrm{CDOM}}(440)$ values in the LPML compared to those in the layer below (i.e., PSW) were found in vertical section of the two channels of the Mackenzie River mouth (Fig. 6b and d). The similar positive correlation between $\mathrm{a}_{\mathrm{CDOM}}(440)$ and salinity was found in the PSW $\left(r^{2}=0.10, p<0.001\right.$; light blue points in Fig. 5b).

In contrast, the relationship turned to be negative in the PWW/UHW (yellow points in Fig. 5b). The coefficient of determination in this layer was higher $\left(r^{2}=0.36\right.$, $p<0.0001)$ than in the LPML and the PSW. Below the PWW/UHW, we found that $\mathrm{a}_{\mathrm{CDOM}}(440)$ values were well correlated with salinity in the LHW $\left(r^{2}=0.63, p<0.01\right.$; orange points in Fig. $5 b$ ). In the $\mathrm{AL}$, the negative correlation was not significant ( $p=0.06$; red points in Fig. $5 b$ ).

The spectral slope of CDOM absorption, $S_{\mathrm{CDOM}}$, is plotted as a function of salinity in Fig. $5 \mathrm{c}$ and d. At salinity $<28$ (in the UPML), $S_{\mathrm{CDOM}}$ values revealed no trend with increasing salinity values (mean value of $0.0192 \pm 0.0011 \mathrm{~nm}^{-1}$ ). Values of $S_{\mathrm{CDOM}}$ for river waters $\left(0.018-0.021 \mathrm{~nm}^{-1}\right)$ fell within the range for sea ice melt waters $\left(0.018-0.022 \mathrm{~nm}^{-1}\right)$.
We found, however, that $S_{\mathrm{CDOM}}$ values were negatively correlated with salinity in both the LPML and the PSW layers $(p<0.01$ and 0.001 , respectively; Fig. 5d). Those negative trends of $S_{\mathrm{CDOM}}$ versus salinity were opposite to the trend in the $\mathrm{a}_{\mathrm{CDOM}}(440)$ versus salinity relationship for those layers (Fig. 5b). No clear trend was observed in $S_{\mathrm{CDOM}}$ versus salinity relationship in the PWW/UHW, the LHW, and the AL layers. Values of $S_{\mathrm{CDOM}}$ varied in each water mass: $0.0189 \pm 0.0006$ S.D. $\left(\mathrm{nm}^{-1}\right)$ for LPML, $0.0177 \pm 0.0006$ S.D. $\left(\mathrm{nm}^{-1}\right)$ for PSW, $0.0171 \pm 0.0003$ S.D. $\left(\mathrm{nm}^{-1}\right)$ for PWW/UHW, $0.0175 \pm 0.0002$ S.D. $\left(\mathrm{nm}^{-1}\right)$ for LHW, and $0.0166 \pm 0.0009$ S.D. $\left(\mathrm{nm}^{-1}\right)$ for AL. Those values were significantly different among the LPML, the PSW, the PWW/UHW, the LHW, and the AL $(p<0.0001$ for the three neighbor water masses and $p<0.05$ for the difference between the LHW and the AL).

\subsection{Relationship between CDOM absorption and its spectral slope}

The relationship between $S_{\mathrm{CDOM}}$ and $\mathrm{a}_{\mathrm{CDOM}}(440)$ varied depending on water masses (Fig. 7). As in the $S_{\mathrm{CDOM}}$ versus salinity relationship, $S_{\mathrm{CDOM}}$ values revealed no trend with increasing a $\operatorname{CDOM}(440)$ values in the UPML (Fig. 7a), which is consistent with those reported in coastal waters at moderate 
latitudes (Vodacek et al., 1997; Babin et al., 2003).

At salinity $\geq 28$ (below the UPML), in contrast, $S_{\text {CDOM }}$ showed a significant and negative correlation with $\mathrm{a}_{\mathrm{CDOM}}(440)$ for all water masses except for the LHW (Fig. 7b). For the LPML, the slope of the $S_{\mathrm{CDOM}}$ versus $\mathrm{a}_{\mathrm{CDOM}}(440)$ relationship was $-0.0351\left(r^{2}=0.37, p<\right.$ $0.0001)$. Relatively similar and negative slopes for that relationship were observed in the PSW and the PWW/UHW (slope $=-0.0231$ and $-0.0582, r^{2}=0.36$ and 0.59 , respectively; $p<0.0001$ for both water masses). Those slopes were not significantly different among the LPML, the PSW, and the PWW/UHW ( $p=0.9$ and 0.06 for the two neighbor water masses, respectively). While there was no relationship between $S_{\mathrm{CDOM}}$ and a $\mathrm{CDOM}(440)$ in the LHW, a negative correlation was again observed in the AL (slope $=-0.1888$, $\left.r^{2}=0.41\right)$.

\subsection{Variability in DOC concentration and its relationship with hydrography}

DOC concentrations varied widely in the Southern Beaufort Sea $(49 \mu \mathrm{M}<\mathrm{DOC}<460 \mu \mathrm{M}$; Fig. $8 \mathrm{a})$. These values mostly fell within the range observed in various environments of the Arctic Ocean (Amon, 2004; Benner et al., 2005). Similarly to $\mathrm{a}_{\mathrm{CDOM}}(440)$ versus salinity relationship, DOC concentrations showed a strong and negative correlation with salinity in the UPML ( $r^{2}=0.89$; Fig. 8a). Note that because DOC concentrations for sea ice melt waters were not obtained in this study, these data points were not used to obtain this regression. Our zero-salinity DOC concentrations were significantly lower than in the Eastern Arctic Ocean $(p<0.0001$; Amon, 2004).

At salinities $\geq 28$ (below the UPML), DOC concentrations tended to decrease gradually with increasing salinity (Fig. 8b), which was a different trend compared to $\mathrm{a}_{\mathrm{CDOM}}(440)$ or $S_{\mathrm{CDOM}}$ versus salinity relationship (Fig. $5 \mathrm{~b}$ and d). The DOC concentrations in these layers were much lower $(65 \pm 6 \mu \mathrm{M})$ than in the layer above (i.e., UPML).

\subsection{Relationship between CDOM absorption properties and DOC concentrations}

To examine the relationship between DOC and $\mathrm{a}_{\mathrm{CDOM}}(440)$, DOC is plotted as a function of $\mathrm{a}_{\mathrm{CDOM}}(440)$ at all depths (Fig. 9a). We found that $\mathrm{a}_{\mathrm{CDOM}}(440)$ showed an excellent correlation with DOC in the UPML $\left(r^{2}=0.97\right.$; Fig. 9a), indicating that $97 \%$ of DOC variability is explained by that in the colored fraction of DOM, namely CDOM, in the surface layer of the Southern Beaufort Sea. However, at salinities $\geq 28$ (below the UPML), no correlation was observed (Fig. 9b). DOC concentrations for all water masses below the UPML were much lower and the mean value of $66 \pm 11 \mu \mathrm{M}$ was obtained.
To examine general properties of CDOM absorption in Arctic waters compared to those at lower latitudes, $S_{\mathrm{CDOM}}$ is plotted as a function of $\mathrm{a}_{\mathrm{CDOM}}^{*}(440)\left(\mathrm{m}^{2} \mathrm{~g}^{-1}\right)$ (i.e., $\mathrm{a}_{\mathrm{CDOM}}(440)$ normalized to DOC; Fig. 10). The $\mathrm{a}_{\mathrm{CDOM}}^{*}(440)$ values were high in the UPML and variable $\left(0.10 \pm 0.07 \mathrm{~m}^{2} \mathrm{~g}^{-1}\right)$. The mean value in the UPML was above the upper limit of oceanic waters $\left(0.07 \mathrm{~m}^{2} \mathrm{~g}^{-1}\right.$; Nelson and Siegel, 2002). In contrast, $\mathrm{a}_{\mathrm{CDOM}}^{*}(440)$ values were low and less variable in the LPML $\left(0.043 \pm 0.010 \mathrm{~m}^{2} \mathrm{~g}^{-1}\right)$.

Below the LPML a significant negative correlation was found between $S_{\mathrm{CDOM}}$ and $\mathrm{a}_{\mathrm{CDOM}}^{*}(440)\left(r^{2}=0.56 ; p<\right.$ 0.0001 ; Fig. 10b). $S_{\mathrm{CDOM}}$ values in the PWW/UHW were significantly lower than in the LHW ( $p<0.0001)$, while both $S_{\mathrm{CDOM}}$ and $\mathrm{a}_{\mathrm{CDOM}}^{*}(440)$ values in the PSW varied widely.

\section{Discussion}

\subsection{Linkages among CDOM absorption, DOC concentrations, and hydrography of the Arctic Ocean}

During the MALINA cruise, we observed large variability in hydrographical conditions and CDOM absorption from coastal to open ocean waters $(0 \leq$ Salinity $<35$ and $\left.0.018<\mathrm{a}_{\mathrm{CDOM}}(440)<1.08 \mathrm{~m}^{-1}\right)$. Although $S_{\mathrm{CDOM}}$ values were similar, $\mathrm{a}_{\mathrm{CDOM}}(440)$ values in sea ice melt water were very low and were well discriminated from those in surrounding waters, and by excluding these data a strong negative correlation between acDOM $(440)$ and salinity was found in the UPML $(<20 \mathrm{~m})$. This result indicates a strong river influence and near-conservative behavior of CDOM in the river plume, which is consistent with previous studies in this region (Bélanger et al., 2006; Matsuoka et al., 2009). According to our observations, the river plume extended far from the western channel of the river mouth to the northwest direction over $150 \mathrm{~km}$. This result is consistent with that reported by Macdonald et al. (1999).

The slope of $\mathrm{a}_{\mathrm{CDOM}}(440)$ versus salinity in the present study was significantly different from that of Bélanger et al. (2006) ( $p<0.0001$; Fig. 5a). A $10 \mathrm{~cm}$ optical pathlength with a traditional spectrophotometer Lambda 35 (PerkinElmer) was used to obtain CDOM absorption coefficients in Bélanger et al. (2006), while we used the same optical pathlength (i.e., $10 \mathrm{~cm}$ ) with an UltraPath. Comparison of the results between a similar spectrophotometer (Perkin-Elmer Lambda 19) and the UltraPath showed a reasonable agreement (see Appendix A2). While CDOM absorption was measured onboard immediately after water sampling in this study, the measurements were achieved a few months after sampling in Bélanger et al. (2006) on frozen water samples. The difference in the slope for $\mathrm{a}_{\mathrm{CDOM}}(440)$ versus salinity relationship could partly result from change in CDOM absorption properties over time or as a result of freezing. 

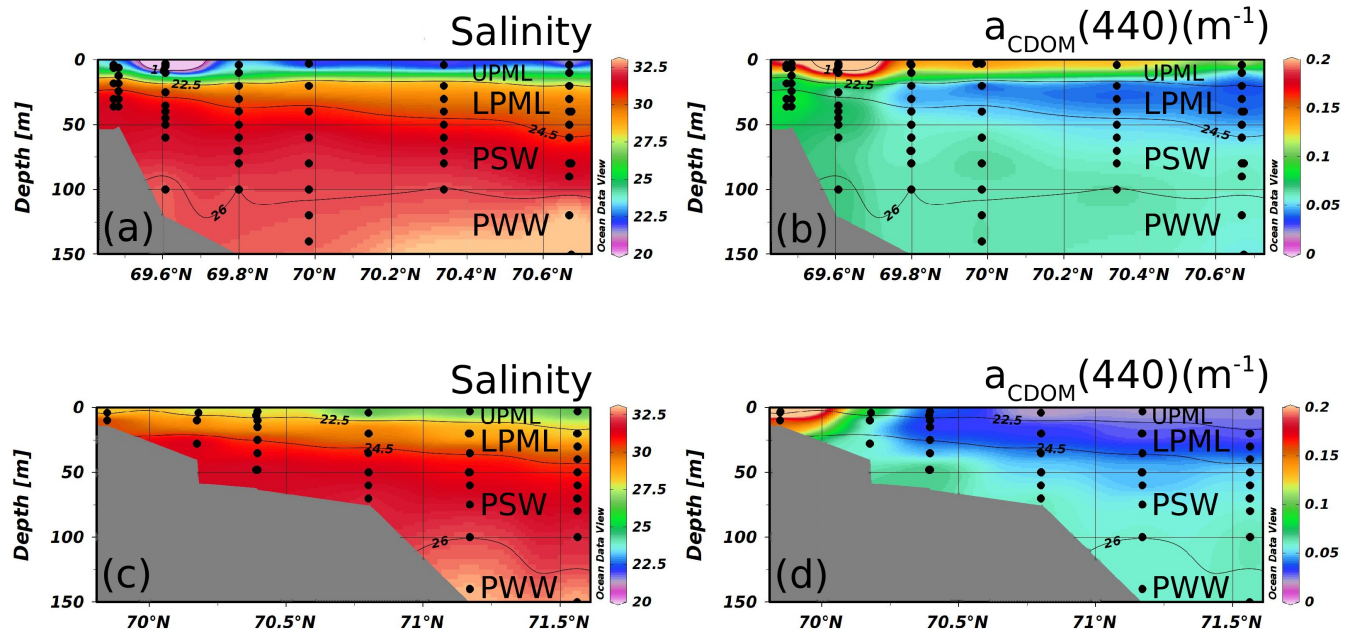

Fig. 6. Vertical section of the two channels of the Mackenzie River (see Fig. 1). (a) Salinity and (b) a CDOM(440) in the western transect and (c) Salinity and (d) $\mathrm{a}_{\mathrm{CDOM}}(440)$ in the eastern transect. Potential density contours of 22.5 , 24.5, and 26 (in $\mathrm{kg} \mathrm{m}^{-3}$ ), which correspond to salinity of $28,30.7$, and 32.3 , respectively, are depicted.

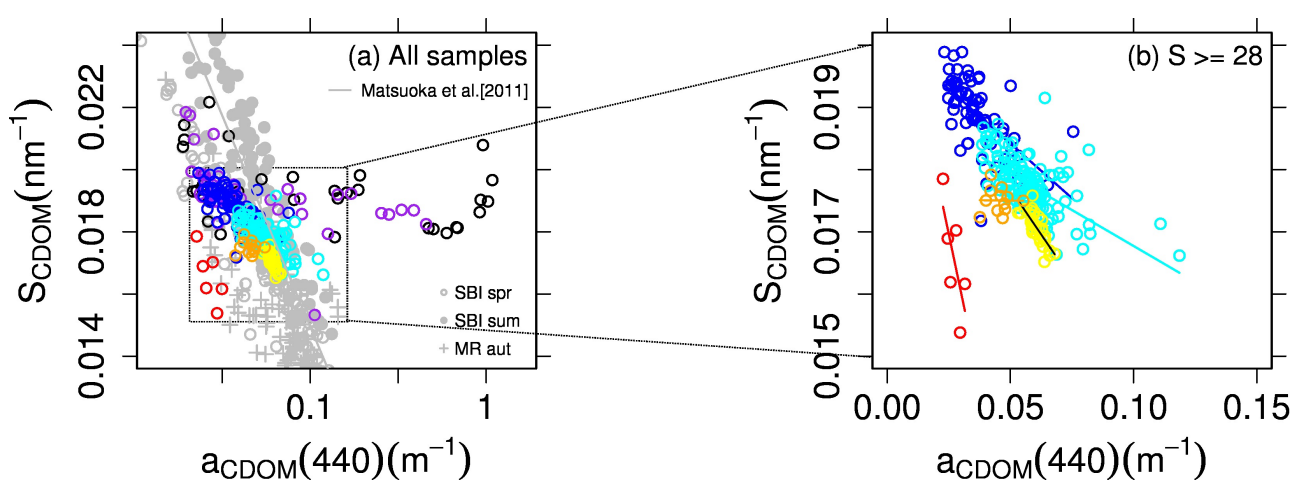

Fig. 7. $S_{\mathrm{CDOM}}$ as a function of $\mathrm{a}_{\mathrm{CDOM}}(440)$ for (a) the whole salinity range and (b) salinity $\geq 28$ (below the UPML). See Fig. 5 for symbols. Data from previous campaigns in the Western Arctic Ocean are also shown: Western Shelf-Basins Interactions (SBI) cruises for spring (SBI spr: grey open circles) and summer (SBI sum: grey closed circles) and Japanese Arctic campaign for autumn (MR aut: grey crosses) (Matsuoka et al., 2011).

The negative correlation between $\mathrm{a}_{\mathrm{CDOM}}(440)$ and salinity was not observed in the LPML, indicating optical properties between the UPML and the LPML were different. Rather, a weak but significant and positive correlation was observed in the LPML. a $\mathrm{CDOM}(440)$ values in this layer were significantly lower than in the layer below, the PSW $(p<0.0001)$. The lower values might be explained by the removal of CDOM from the water mass due to brine rejection during fall. This phenomenon was demonstrated in laboratory experiments (Amon, 2004), and observed over Russian shelves in autumn as a significant mechanism for the export of terrigenous dissolved organic nitrogen (Dittmar, 2004). The similar positive correlation between $\mathrm{a}_{\mathrm{CDOM}}(440)$ and salinity was also found in the PSW. The higher $\mathrm{a}_{\mathrm{CDOM}}(440)$ values in this water mass compared to that in the layer above is likely attributed to the transport of CDOM by the lateral intrusion of waters into the PSW layer from the Bering Sea during summer (Matsuoka et al., 2011).

In the Arctic Ocean, phytoplankton blooms occur in near surface waters in early spring, and a deep chlorophyll maximum is developed around 60-80 $\mathrm{m}$ depth (defined as PSW in this study) in summer in our study area (e.g., Fig. 3e; Tremblay et al., 2008). During our observations, there was a significant and positive correlation between $\mathrm{a}_{\mathrm{CDOM}}(440)$ and chl $a$ concentration $\left(r^{2}=0.35\right.$ and 0.32 for surface and PSW, respectively; $p<0.05$ and $<0.001$, respectively). This result suggests that autochthonous CDOM could be produced as a result of phytoplankton degradation in these layers, and contribute to the CDOM pool. 


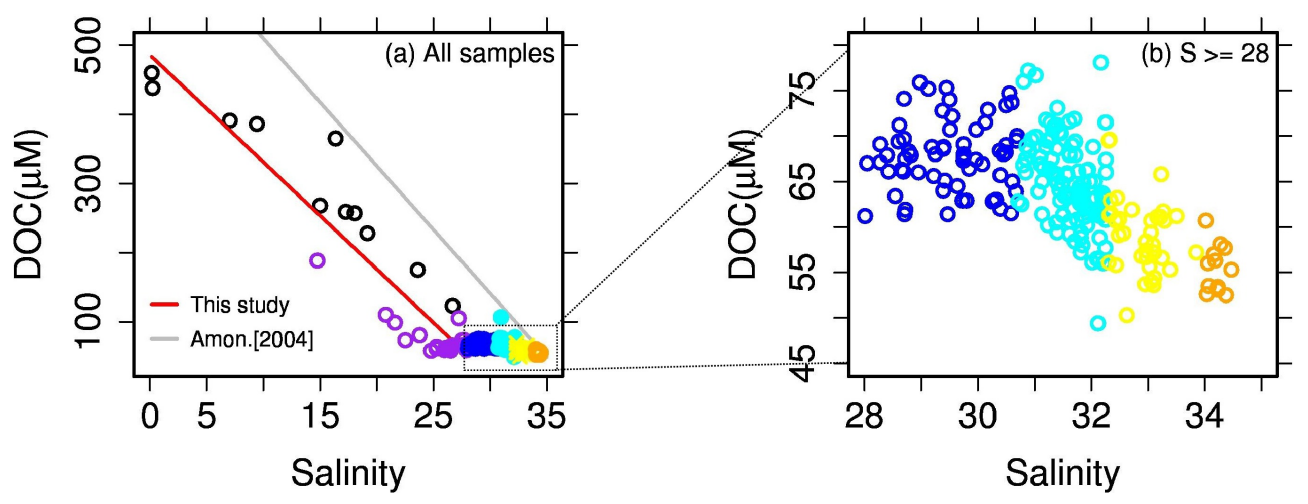

Fig. 8. Relationship between DOC and salinity $(S$ ) for (a) the whole range and (b) $S \geq 28$ (below the UPML). See Fig. 5 for symbols. A linear fit provides the DOC vs. salinity relationship: $\mathrm{DOC}=486-16^{*} \mathrm{~S}\left(r^{2}=0.89 ; p<0.0001\right)$.

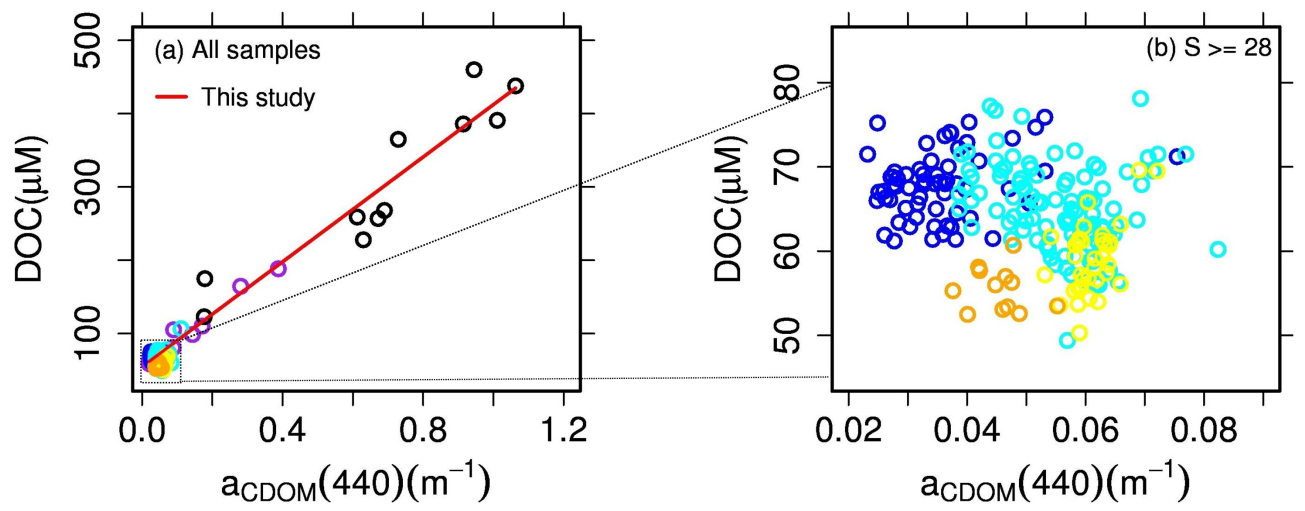

Fig. 9. Relationship between DOC and $\mathrm{a}_{\mathrm{CDOM}}(440)$ for (a) the whole salinity range and (b) salinity $\geq 28$ (below the UPML). See Fig. 5 for symbols. A linear fit provides the following relationship: $\mathrm{DOC}=55+357 * \mathrm{a} \mathrm{CDOM}(440)\left(r^{2}=0.97 ; p<0.0001\right)$.

The relationship between acDOM(440) and salinity was significantly negative in the PWW/UHW and LHW, suggesting the waters originated from Arctic coastal areas. This assumption is partly supported by the fact that the PWW/UHW is formed in the Alaskan coastal regions and/or coastal polynyas (Winsor and Chapman, 2002), whereas the LHW is formed in the Barents Sea during sea ice formation (Aagaard et al., 1989). It is noted that the coefficient of determination was significant and relatively high in the LHW $\left(r^{2}=0.63, p<0.01\right)$. If this negative correlation were extrapolated to zero-salinity, $\mathrm{a}_{\mathrm{CDOM}}(440)$ value at zero-salinity $\left(0.93 \mathrm{~m}^{-1}\right)$ would be close to the one reported for Kara Sea $\left(1.3 \mathrm{~m}^{-1}\right.$ : Aas et al., 2002), which is adjacent to the Barents Sea $\left(\mathrm{a}_{\mathrm{CDOM}}(440)\right.$ values for the Barents Sea are not available). Although the coefficient of determination was not so high, this result suggests that the observed CDOM could partly originate in coastal areas receiving riverine discharge.

The $S_{\mathrm{CDOM}}$ values were significantly different among the LPML, the PSW, PWW/UHW, and the LHW $(p<0.0001$ for the three neighbor water masses). Carder et al. (1989) and Blough and Del Vecchio. (2002) showed the magnitude of $\mathrm{S}_{\mathrm{CDOM}}$ value varies due to bulk sources and/or local pro- cesses of CDOM. General properties of $S_{\mathrm{CDOM}}$ are further discussed at the end of this section with $\mathrm{a}_{\mathrm{CDOM}}^{*}(440)$ values.

No trends between $S_{\mathrm{CDOM}}$ and a $\mathrm{CDOM}_{\mathrm{CDO}}(440)$ were evident in the UPML, which is consistent with observations in surface coastal waters at moderate latitudes (Vodacek et al., 1997; Babin et al., 2003). $S_{\text {CDOM }}$ and a CDOM $(440)$ were inversely related in several deeper water masses (except the LHW) as reported previously in polar waters (e.g., Matsuoka et al., 2011). Relationships between $S_{\mathrm{CDOM}}$ and a are influenced by sources, transformations, or both (Carder et al., 1989; Twardowski and Donaghay, 2002). The negative correlations observed in this study were not very strong, so it is difficult to determine the relative contributions of sources and transformations on CDOM absorption properties.

We observed highly variable DOC concentrations in the southern Beaufort Sea, which is consistent with observations in other Arctic waters (e.g. Guay et al., 1999; Benner et al., 2005). A negative relationship between DOC concentration and salinity was observed in the UPML $\left(r^{2}=0.89\right)$, indicating the influence of the Mackenzie River on surface water DOC concentrations in the Southern Beaufort Sea. Below the UPML, the concentrations of DOC $(65 \pm 6 \mu \mathrm{M})$ were much 


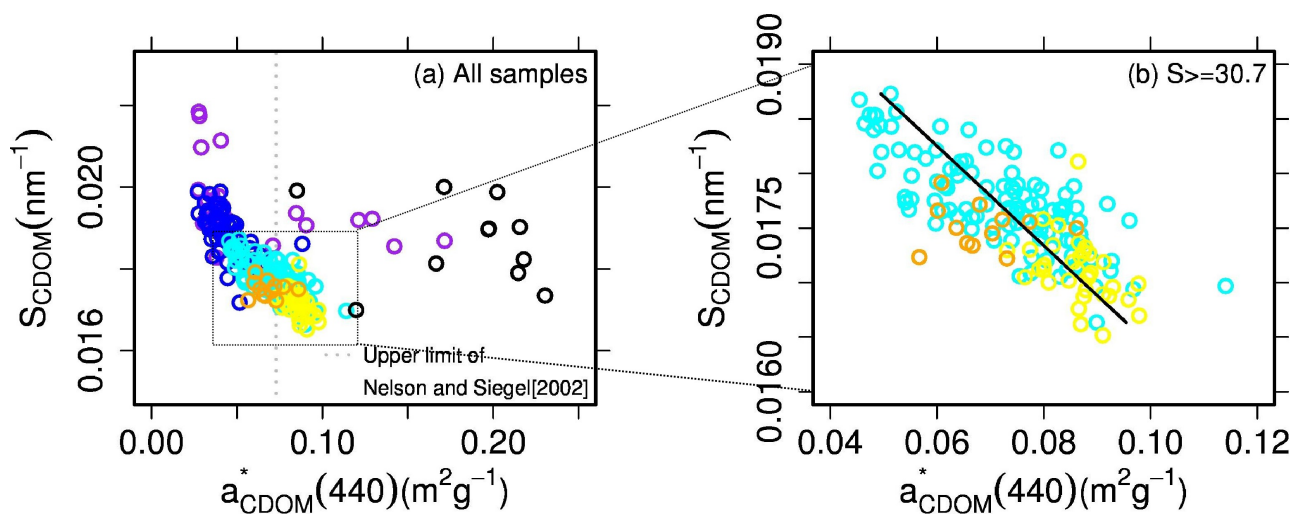

Fig. 10. Variations of $S_{\mathrm{CDOM}}$ vs. a $\mathrm{CDOM}^{*}$ (440) for (a) the whole salinity range and (b) salinity $\geq 30.7$. The upper limit from Nelson and Siegel (2002) is depicted as a dotted line. To obtain those values, a ${ }_{\mathrm{CDOM}}(440)$ was estimated from a $\mathrm{CDOM}(325)$ by assuming $S_{\mathrm{CDOM}}=$ $0.015 \mathrm{~nm}^{-1}$. See Fig. 5 for symbols. A linear fit provides the following relationship: $S_{\mathrm{CDOM}}=0.021-0.046^{*} \mathrm{a}_{\mathrm{CDOM}}^{*}(440)\left(r^{2}=0.56\right.$; $p<0.0001)$.

lower, indicating different sources of DOC in these water masses. The differences in optical characteristics between surface and subsurface water masses also indicated differences in the composition of DOC. At zero-salinity, DOC concentrations at the mouth of the Mackenzie River were lower than those measured in major Siberian Rivers (Amon, 2004; Raymond et al., 2007). The lower zero-salinity DOC concentrations in the Western Arctic Ocean $(486 \mu \mathrm{M}$ obtained from this study) relative to that in the Eastern Arctic Ocean $(694 \mu \mathrm{M}$ obtained from Amon, 2004) is likely due to lower DOC concentrations in high latitude watersheds of North America compared to those in Siberia (Raymond et al., 2007).

The peak DOC flux from the Mackenzie River, which occurs during ice melt in the early spring (e.g., Carmack et al., 2004; Holmes et al., 2008), was prior to the MALINA cruise. The contribution of DOC during the freshet is likely important in terms of the DOC budget and should be taken into account (Holmes et al., 2008). In addition, some of the DOC delivered by river discharge during that time period is bioavailable, thereby stimulating microbial processes (Moran and Zepp, 1997). Thus, more detailed observation of DOC concentrations, especially in this time period, is required to understand biogeochemical processes.

Our mean value of $\mathrm{a}_{\mathrm{CDOM}}^{*}(440)$ was $0.10 \pm 0.07$ in the UPML, which was higher than the upper limit of this value for oceanic waters $\left(0.07 \mathrm{~m}^{2} \mathrm{~g}^{-1}\right.$; Nelson and Siegel, 2002). Our mean value of $a_{C D O M}^{*}(440)$ in the LPML was $0.043 \pm 0.010$, which was much lower and less variable compared to that in the UPML. This suggests that river influence is greatest in surface waters ( $<20 \mathrm{~m}$ depth: within UPML), which is consistent with previous findings in this region (e.g., Macdonald et al., 1989; Carmack et al., 2004).

Below the LPML, there was a negative correlation between $S_{\mathrm{CDOM}}$ and $\mathrm{a}_{\mathrm{CDOM}}^{*}(440)$. From laboratory experiments, Moran et al. (2000) and Helms et al. (2008) demon- strated that microbial activities are associated with a decrease in $S_{\mathrm{CDOM}}$ over time, which is opposite to the effect of photobleaching by solar irradiation (Moran et al., 2000; Blough and Del Vecchio, 2002; Twardowski and Donaghay, 2002; Helms et al., 2008). Our lower $S_{\mathrm{CDOM}}$ (or higher $\mathrm{a}_{\mathrm{CDOM}}^{*}(440)$ ) values in the PWW/UHW compared to those in the LHW could result from microbial activities. A slightly but significantly higher value of $\mathrm{AOU}$ in the PWW/UHW $(90 \pm 1 \mu \mathrm{M})$ than in the LHW $(75 \pm 1 \mu \mathrm{M})$ could partly support more biological consumption over time in the PWW/UHW than in the LHW $(p<0.0001)$. These water masses also have different sources, which could contribute to the observed differences in $S_{\mathrm{CDOM}}$. While transport of CDOM for Arctic waters is mainly explained by hydrography, CDOM absorption properties such as $S_{\mathrm{CDOM}}$ for each water mass seem to be partly influenced by local microbial processes especially in the PWW/UHW and the LHW. More detailed knowledge about the differences in sources of CDOM between Western and Eastern Arctic Ocean are needed to investigate this further.

\subsection{Implications for estimating DOC concentrations in the surface layer of the Southern Beaufort Sea using satellite ocean color remote sensing}

In this study, we found that DOC concentrations were highly correlated with aCDOM $(440)$ in the UPML $\left(r^{2}=0.97\right)$, which is consistent with recent papers (e.g., Mannino et al., 2008; Fichot and Benner, 2011). In particular, our regression was similar with that obtained in the U.S. Middle Atlantic Bight (Mannino et al., 2008; DOC vs. aCDOM(440) relationship was obtained assuming a $S_{\mathrm{CDOM}}$ of $0.018 \mathrm{~nm}^{-1}$ to convert $\mathrm{a}_{\mathrm{CDOM}}(412)$ to $\left.\mathrm{a}_{\mathrm{CDOM}}(440)\right)$. This result suggests that a similar positive correlation can be applied to both areas to estimate DOC concentrations using a

The strong correlation between DOC concentrations and $\mathrm{a}_{\mathrm{CDOM}}(440)$ in the UPML obtained in this study suggests 
that when $\mathrm{aCDOM}_{\mathrm{C}}(440)$ values are obtained using ocean color remote sensing, DOC concentrations can be also estimated from satellite. Recently, Bélanger et al. (2008) developed an empirical ocean color algorithm to derive the ratio of $\mathrm{a}_{\mathrm{CDOM}}(\lambda)$ to $\mathrm{a}_{t}(\lambda)$ at $412 \mathrm{~nm}$ for coastal water environments using global datasets that include samples from the Southern Beaufort Sea. In addition, previous papers indicated that $\mathrm{a}_{t}(\lambda)$ can be estimated accurately for Arctic waters using an inversion model such as Lee's quasi-analytical algorithm (QAA) (Lee et al., 2002, 2009; Bélanger et al., 2006; Matsuoka et al., 2007). Combining those two algorithms together with DOC versus $\mathrm{a}_{\mathrm{CDOM}}(440)$ relationship, it is now possible to estimate DOC concentrations in the surface layer (i.e., UPML) of the Southern Beaufort Sea using satellite ocean color data. This kind of semi-analytical method is further useful for estimating DOC budgets for Arctic coastal waters. Note that the relationship between $\mathrm{a}_{\mathrm{CDOM}}(440)$ and DOC might be influenced by changes in the fraction of freshwater due to ice-melt conditions. Thus, estimates of DOC concentrations could be biased in these waters and should be considered with caution.

\section{Conclusions}

Our results show that $\mathrm{a}_{\mathrm{CDOM}}(440)$ is a useful seawater property to distinguish water masses when combined with other readily measured properties such as salinity. It allowed us to better describe the local distribution of water masses in the Southern Beaufort Sea. For extensive surveys, CDOM absorption can be determined using its fluorescence signal ( $\left.f_{\mathrm{CDOM}}\right)$ once the relationship between $\mathrm{a}_{\mathrm{CDOM}}(440)$ and $\mathrm{f}_{\mathrm{CDOM}}$ is established (see Appendix A3). On few occasions, $\mathrm{f}_{\mathrm{CDOM}}$ measurements have been combined with CTD deployments in the frame of large-scale surveys in Arctic Ocean (Amon, 2004). The use of new sampling platforms such as profiling floats and underwater gliders in the Arctic Ocean is developing. Measurements of $\mathrm{f}_{\mathrm{CDOM}}$ on those platforms together with measurements of temperature, salinity, oxygen using an optode, and nitrate using a miniaturized in situ UV spectrophotometer (Johnson et al., 2009) may soon allow describing the pan-arctic distribution of water masses.

While transport of CDOM in Arctic waters is mainly driven by hydrography, CDOM absorption properties such as $S_{\mathrm{CDOM}}$ for each water mass seem to partly reflect local microbial activities, especially in the PWW/UHW and the LHW, which is consistent with previous results (Nelson et al., 1998). More detailed analyses are necessary to better understand the linkages.

In terms of ocean color applications, a tight relationship between CDOM absorption and DOC is useful to estimate DOC concentrations in the surface layer using satellite ocean color data, especially in southern Beaufort Sea waters. Assuming that DOC concentrations in the surface layer decrease linearly to the bottom of the mixed layer, where DOC
Table A1. Coefficients of the $\mathrm{a}_{\mathrm{CDOM}}(440)$ versus $\mathrm{f}_{\mathrm{CDOM}}$ relationship for each water mass of the Southern Beaufort Sea.

\begin{tabular}{llllll}
\hline Water mass & Intercept & Slope & $r^{2}$ & p-value & $\mathrm{N}$ \\
\hline UPML + LPML & -0.073 & 1.332 & 0.71 & $<0.0001$ & 79 \\
PSW & -0.014 & 0.730 & 0.71 & $<0.0001$ & 111 \\
PWW & 0.084 & -0.196 & 0.10 & $<0.05$ & 33 \\
LHW + AW & -0.030 & 0.664 & 0.93 & $<0.0001$ & 18 \\
\hline
\end{tabular}

concentrations are relatively constant, it is possible to estimate DOC budget in the water column. This work is required to understand modification in DOC budget for Arctic waters in the context of ongoing global warming.

\section{Appendix A}

Variability in CDOM absorption for difference waters

\section{A1 Difference in CDOM absorption between water samples from the CTD/Niskin and from the barge/zodiac}

We examined the difference in acDOM $(440)$ values between samples collected from the CTD/Niskin and those collected from the barge or zodiac in Arctic waters (Fig. A1). When all data points were analyzed (except one outlier, dotted circle in Figure A1a), $\mathrm{a}_{\mathrm{CDOM}}(440)$ values were significantly higher for samples collected from the barge or zodiac (Fig. A1a; $p<0.0001)$. This still hold true when considering only the low aCDOM $(440)$ values $\left(<0.2 \mathrm{~m}^{-1}\right.$; Fig. A1b; $\left.p<0.0001\right)$. These results suggest that a thin layer (i.e., 0 to $0.5 \mathrm{~m}$ depth) exists at the surface of the Arctic Ocean, in which $\mathrm{a}_{\mathrm{CDOM}}(440)$ value is significantly higher than in the deeper layers. The thin layer of the Arctic Ocean seems to be formed by freshwater input of river discharge, sea ice melt, or both (see Fig. 6 for example). This fact could have important implications for satellite ocean color remote sensing applied to Arctic waters.

\section{A2 Comparison of CDOM absorption between a liquid waveguide system and a traditional spectrophotometer}

We examined the differences in $\mathrm{a}_{\mathrm{CDOM}}(440)$ values between a liquid waveguide system (UltraPath) and a traditional spectrophotometer (Perkin-Elmer Lambda 19) (Fig. A2) for three samples. For this comparison, a $10 \mathrm{~cm}$ optical pathlength was used for both instruments. The ratio of $\mathrm{a}_{\mathrm{CDOM}}(440)$ values measured using a Lambda 19 (L) and using an UltraPath (U) varied from 0.74 to 1.02 (Fig. A2a-c), but the corresponding coefficient of determination varied on average between 


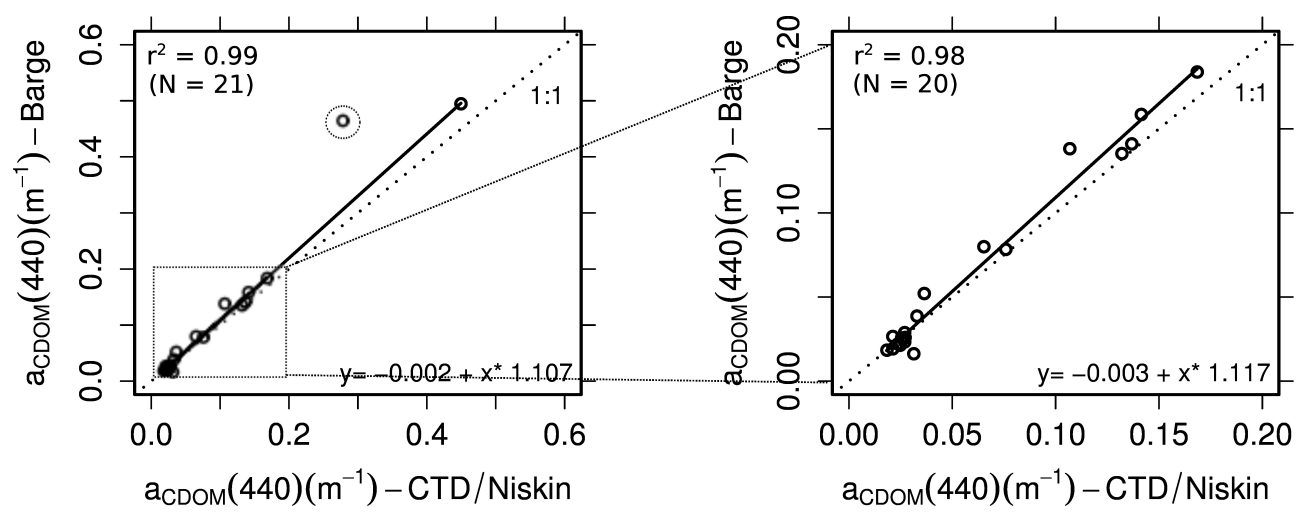

Fig. A1. Comparison of $\mathrm{a}_{\mathrm{CDOM}}(440)$ values between samples from a CTD/Niskin and from a barge. (a) $\mathrm{a}_{\mathrm{CDOM}}(440)-\mathrm{Barge}$ vs. $\mathrm{a}_{\mathrm{CDOM}}(440)-\mathrm{CTD} / \mathrm{Niskin}$ at $\mathrm{a}_{\mathrm{CDOM}}(440)<0.5 \mathrm{~m}^{-1}$ (all data points included, $\mathrm{N}=22$ ) and (b) $\mathrm{a}_{\mathrm{CDOM}}(440)$ - $\mathrm{Barge}$ vs. $\mathrm{a}_{\mathrm{CDOM}}(440)$ $\mathrm{CTD} /$ Niskin at $\mathrm{a}_{\mathrm{CDOM}}(440)<0.20 \mathrm{~m}^{-1}(\mathrm{~N}=20)$. In both cases, the slope of $\mathrm{a}_{\mathrm{CDOM}}(440)$-Barge vs. $\mathrm{a}_{\mathrm{CDOM}}(440)-\mathrm{Niskin}$ relationship was found to be significantly different from 1 ( $p<0.0001$ for both figures a and $b)$.
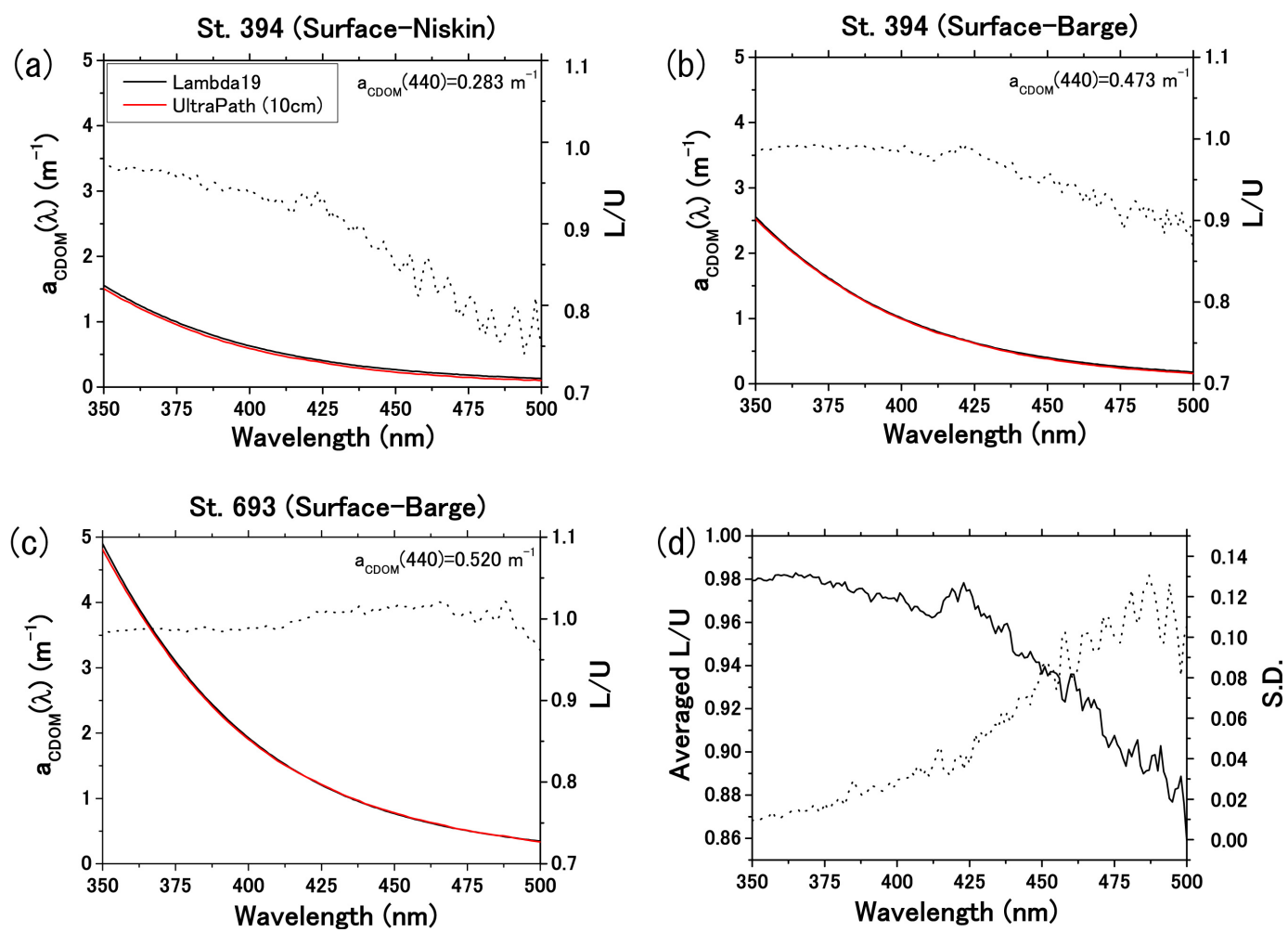

Fig. A2. Comparison of CDOM absorption spectra between a liquid waveguide system (UltraPath) and a traditional spectrophotometer (Lambda 19) at (a) station 394 (water from Niskin), (b) station 394 (water from barge), and (c) station 693 (water from barge). (d) average value of the ratio $(\mathrm{L} / \mathrm{U})$ between values measured with the Lambda 19 spectrophotometer $(\mathrm{L})$ and with the Ultrapath (U) and its standard deviation (dotted curve) within the spectral range from 350 to $500 \mathrm{~nm}$ (where the spectral slope of CDOM absorption is calculated). 


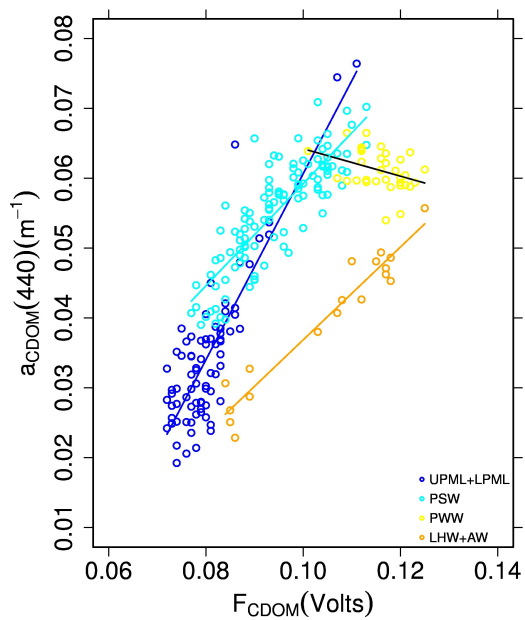

Fig. A3. Relationship between $\mathrm{a}_{\mathrm{CDOM}}(440)$ and CDOM fluorescence, $\mathrm{f}_{\mathrm{CDOM}}$, for water masses of the Southern Beaufort Sea. Data points for UPML + LPML, PSW, PWW, and LHW + AW are shown as blue, cyan, yellow, and orange open circles, respectively.

0.98 (at $350 \mathrm{~nm}$ ) and 0.86 (at $500 \mathrm{~nm}$ ) in the spectral domain from 350 to $500 \mathrm{~nm}$ where $S_{\mathrm{CDOM}}$ was calculated. This result suggests that $\mathrm{a}_{\mathrm{CDOM}}(440)$ values measured using both instruments agree reasonably well.

\section{A3 Relationships between CDOM absorption and fluorescence for water masses of the Southern Beaufort Sea}

While CDOM absorption is a useful seawater property to distinguish water masses when combined with other readily measured properties such as salinity, continuous field measurements at high spatial resolution are impractical. Instead, a CDOM fluorometer can be easily combined with autonomous instruments such as profiling floats and underwater gliders, therefore allowing $\mathrm{f}_{\mathrm{CDOM}}$ measurements to be conducted for extensive surveys. In addition, high resolution in situ measurements of $\mathrm{f}_{\mathrm{CDOM}}$ using a WetStar fluorometer have been found to be an excellent predictor of $\operatorname{acDOM}(\lambda)$ in various aquatic systems (Belzile et al., 2006).

By exciting light in the wavelength ranging from $\lambda_{1}$ to $\lambda_{2} \mathrm{~nm}$ to a target, $\mathrm{f}_{\mathrm{CDOM}}$ captures the emitted light at the wavelength $\lambda_{3}$ within an acceptance angle using a Backscat 1 fluorometer (350, 460, and 550 for $\lambda_{1}, \lambda_{2}$, and $\lambda_{3} \mathrm{~nm}$, respectively in this study). Instead, CDOM absorption is a bulk measurement of total light absorbed by a water sample in a spectral range (e.g., 200 to $700 \mathrm{~nm}$ in this study). Since both $\mathrm{f}_{\mathrm{CDOM}}$ and $\mathrm{a}_{\mathrm{CDOM}}(\lambda)$ are related to the optical fraction of DOM, they usually covary in natural waters, but the ratio between $\mathrm{f}_{\mathrm{CDOM}}$ and $\mathrm{a}_{\mathrm{CDOM}}(\lambda)$ depends on the fluorescence quantum yield of the various fluorophores present in the water masses (Zepp et al., 2004; Belzile et al., 2006).
In this study, we examined the relationship between discrete $\mathrm{a}_{\mathrm{CDOM}}(440)$ (filtered through $0.2 \mu \mathrm{m}$ membrane) and in situ $\mathrm{f}_{\mathrm{CDOM}}$ (unfiltered) for water masses of the Southern Beaufort Sea (Fig. A3 and Table A1). At salinity $<30.7$ (i.e., UPML + LPML), $\mathrm{a}_{\mathrm{CDOM}}(440)$ was significantly and positively correlated with $\mathrm{f}_{\mathrm{CDOM}}\left(r^{2}=0.71, p<0.0001\right.$; Fig. A3). A similar strong positive correlation was observed for PSW $\left(r^{2}=0.71, p<0.0001\right)$, but with a lower slope. For PWW, there was a weak but significant correlation between $\mathrm{a}_{\mathrm{CDOM}}(440)$ and $\mathrm{f}_{\mathrm{CDOM}}\left(r^{2}=0.10, p<0.05\right)$. Although more detailed analyses are required, this negative correlation could result from a microbial production (uptake) of light absorbing material together with the uptake (production) of a fluorophore substance. At salinity $\geq 33.9$ (i.e., LHW + AW), a positive correlation was again observed $\left(r^{2}=\right.$ $0.93, p<0.0001)$. Slopes and intercepts for $\mathrm{a}_{\mathrm{CDOM}}(440)$ versus $\mathrm{f}_{\mathrm{CDOM}}$ relationships are summarized in Table A1. As expected, if $\mathrm{a}_{\mathrm{CDOM}}\left(\lambda_{k}\right)$ (with $\lambda_{k} \mathrm{~nm}=380 \mathrm{~nm}$ within the wavelengths of excited light) is used instead of $\mathrm{a}_{\mathrm{CDOM}}(440)$, the correlation for each water mass is higher, except for PSW $\left(r^{2}=0.74,0.62,0.17\right.$, and 0.96 for UPML + LPML, PSW, PWW, and LHW + AW, respectively). Using those coefficients, $\mathrm{a}_{\mathrm{CDOM}}(440)$ can be derived from the $\mathrm{f}_{\mathrm{CDOM}}$ value alone in different water masses, as measured in the field, which gives access to estimates of $\mathrm{a}_{\mathrm{CDOM}}(440)$ at high spatial resolution.

Acknowledgements. We are grateful to the captain and crews of the Canadian Icebreaker CCGS Amundsen. We also thank S. Hooker, and J. Ehn for their assistance in the collection of data for this study. Comments by three anonymous reviewers are appreciated. This research was funded by the Centre National d'Études Spatiales (CNES) for MALINA Arctic expedition. R. Benner acknowledges funding from the U.S. National Science Foundation (0713915).

Edited by: E.Boss

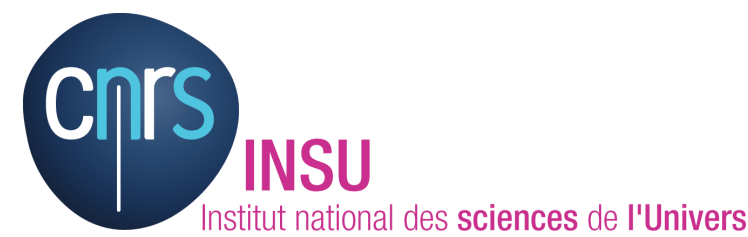

The publication of this article is financed by CNRS-INSU. 


\section{References}

Aagaard, K.: A synthesis of the Arctic Ocean circulation, Cons. Int. Explor. Mer., 188, 11-22, 1989.

Aagaard, K. and Carmack, E. C.: The role of sea ice and other fresh water in the Arctic circulation, J. Geophys. Res., 94, 1448514498, 1989.

Aas, E., Hokedal, J., Hojerslev, N. H., Sandvik, R., and Sakshaug, E.: Spectral properties and UV-attenuation in Arctic marine waters, in: UV radiation and Arctic ecosystems, edited by: Hessen D. O., Springer, Berlin, 2002.

Amon, R.: The role of dissolved organic matter for the organic carbon cycle in the Arctic Ocean, in: The organic carbon cycle in the Arctic Ocean, edited by: Stein R. and Macdonald R. W., Springer, New York, 2004.

Babin, M., Stramski, D., Ferrari, G. M., Claustre, H., Bricaud, A., Obolensky, G., and Hoepffner, N.: Variations in the light absorption coefficients of phytoplankton, nonalgal particles, and dissolved organic matter in coastal waters around Europe, J. Geophys. Res., 108, doi:10.1029/2001JC000882, 2003.

Bélanger, S., Xie, H., Krotkov, N., Larouche, P., Vincent, W. F., and Babin, M.: Photomineralization of terrigenous dissolved organic matter in Arctic coastal waters from 1979 to 2003: Interannual variability and implications of climate change, Global Biogeochem. Cycles, 20, doi:10.1029/2006GB002708, 2006.

Bélanger, S., Babin, M., and Larouche, P.: An empirical ocean color algorithm for estimating the contribution of chromophoric dissolved organic matter to total light absorption in optically complex waters, J. Geophys. Res., 113, doi:10.1029/2007JC004436, 2008.

Belzile, C., Roesler, C. S., Christensen, J. P., Shakhova, N., and Semiletov, I.: Fluorescence measured using the WETStar DOM fluorometer as a proxy for dissolved organic absorption, Estuar. Coast. Shelf Sci., 67, 441-449, 2006.

Benner, R. and Strom, M.: A critical evaluation of the analytical blank associated with DOC measurements by high-temperature catalytic oxidation, Mar. Chem., 41, 153-160, 1993.

Benner, R., Louchouarn, P., and Amon, R. M. W.: Terrigenous dissolved organic matter in the Arctic Ocean and its transport to surface and deep waters of the North Atlantic, Global. Biogeochem. Cycles., 19, GB2025, doi:10.1029/2004GB002398, 2005.

Blough, N. V. and Del Vecchio, R.: Chromophoric DOM in the coastal environment, in: Biogeochemistry of marine dissolved organic matter, edited by: Hansell D. A. and Carlson C. A., Academic press, California, 2002.

Bricaud, A., Morel, A., and Prieur, L.: Absorption by dissolved organic matter of the sea (yellow substance) in the UV and visible domains, Limnol. Oceanogr., 26(1), 43-53, 1981.

Bricaud, A., Babin, M., Claustre, H., Ras, J., and Tièche, F.: Light absorption properties and absorption budget of Southeast Pacific waters, J. Geophys. Res., 115, doi:10.1029/2009JC005517, 2010.

Camill, P.: Permafrost thaw accelerates in boreal peatlands during late-20th century climate warming, Climatic Change, 68, 135$152,2005$.

Carder, K. L., Steward, R. G., Harvey, G. H., and Ortner, P. B.: Marine humic and fulvic acids: Their effects on remote sensing of ocean chlorophyll, Limnol. Oceanogr., 34, 68-81, 1989.
Carmack, E. C., Macdonald, R. W., and Papadakis, J. E.: Water mass structure and boundaries in the Mackenzie shelf estuary, J. Geophys. Res., 94, 18043-18055, 1989.

Carmack, E., Macdonald, R. W., and Jasper, S.: Phytoplankton productivity on the Canadian Shelf of the Beaufort Sea, Mar. Ecol. Prog. Ser., 277, 37-50, 2004.

Coachman, L. K., Aagaard, K., and Tripp, R. B.: Bering strait, The university of Washington press, 172 pp., 1975.

Codispoti, L. A., Flagg, C., Kelly, V., and Swift, J. H.: Hydrographic conditions during the 2002 SBI process experiments, Deep Sea Res. Pt. 2, 52, 3199-3226, 2005.

Dittmar, T.: Evidence for terrigenous dissolved organic nitrogen in the Arctic deep Sea, Limnol. Oceanogr., 49, 148-156, 2004.

Emmerton, C. A., Lesack, L. F. W., and Vincent, W. F.: Nutrient and organic matter patters across the Mackenzie river, estuary and shelf during the seasonal recession of sea-ice, J. Mar. Sys., 74, 741-755, 2008.

Fichot, C. G., and Benner, R.: A novel method to estimate DOC cocentrations from CDOM absorption coefficients in coastal waters, Geophys. Res. Lett. 38, doi:10.1029/2010GL046152, 2011.

Guay, C. K., Klinkhammer, G. P., Falkner, K. K., Benner, R., Coble, P. G., Whitledge, T. E., Black, B., Bussell, F. J., and Wagner, T. A.: High-resolution measurements of dissolved organic carbon in the Arctic Ocean by in-situ fiber- optic spectrometry. Geophys. Res. Lett. 26, 1007-1010, 1999.

Helms, J. R., Stubbins, A., Ritchie, J. D., and Minor, E. C.: Absorption spectral slopes and slope ratios as indicators of molecular weight, sources, and photobleaching of chromophoric dissolved organic matter, Limnol. Oceangr., 53, 955-969, 2008.

Hill, V.: Impacts of chromophoric dissolved organic material on surface ocean heating in the Chukchi Sea, J. Geophys. Res., 113, doi:10.1029/2007JC004119, 2008.

Holmes, R. M., McClelland, J. W., Peterson, B. J., Shiklomanov, I. A., Shiklomanov, A. I., Zhulidov, A. V., Gordeev, V. V., and Bobrovitskaya, N. N.: A circumpolar perspective on fluvial sediment flux to the Arctic Ocean, Global Biogeochem. Cycles, 16(4), doi:10.1029/2001GB001849, 2002.

Holmes, R. M., McClelland, J. W., Raymond, P. A., Franzer, B. B., Peterson, B. J., and Stieglitz, M.: Lability of DOC transported by Alaskan rivers to the Arctic Ocean, Geophys. Res. Lettr., 35, L03402, doi:10.1029/2007GL032837, 2008.

Johnson K. S., Berelson, W. M., Boss, E. S., Chase, Z., Claustre, H., Emerson, S. R., Gruber, N., Körtzinger, A., Perry, M. J. and Riser, S. C.: Observing biogeochemical cycles at global scales with profiling floats and gliders: prospects for a global array. Oceanography, 22(3), 216-225, 2009.

Kirk, J. T. O.: Light and Photosynthesis in Aquatic Ecosystems, 2 Edn., Cambridge Univ. Press, New York, 1994.

Lee, Z. P., Carder, K. L., and Arnone, R. A.: Deriving inherent optical properties from water color: a multiband quasi-analytical algorithm for optically deep waters, Appl. Opt., 41, 5755-5772, 2002.

Lee, Z. P., Lubac, B., Werdell, J., and Arnone, R.: An update of the Quasi-Analytical Algorithm (QAA_v5), available at http://www. ioccg.org/groups/Software_OCA/QAA_v5.pdf, 2009.

Macdonald, R. W., Carmack, E. C., McLaughlin, F. A., Iseki, K., Macdonald, D. M., and O'Brien, M. C.: Composition and modification of water masses in the Mackenzie shelf estuary, J. Geophys. Res., 94, 18057-18070, 1989. 
Macdonald, R. W., Carmack, E. C., McLaughlin, F. A., Falkner, K. K., and Swift, J. H.: Connections among ice, runoff and atmospheric forcing in the Beaufort Gyre, Geophys. Res. Lett., 26, 2223-2226, 1999.

Mannino, A., Russ, M. E., and Hooker, S. B.: Algorithm development and validation for satellite-derived distributions of DOC and CDOM in the U.S. Middle Atlantic Bight, J. Geophys. Res., 113, C07051, doi:10.1029/2007JC004493, 2008.

Matsuoka, A., Larouche, P., Poulin, M., Vincent, W., and Hattori, H.: Phytoplankton community adaptation to changing light levels in the southern Beaufort Sea, Canadian Arctic, Estuar. Coast. Shelf Sci., 82, 537-546, 2009.

Matsuoka, A., Hill, V., Huot, Y., Bricaud, A., and Babin, M.: Seasonal variability in the light absorption properties of western Arctic waters: parameterization of the individual components of absorption for ocean color applications, J. Geophys. Res., 116, doi:10.1029/2009JC005594, 2011.

Matsuoka, A., Huot, Y., Shimada, K., Saitoh, S., and Babin, M.: Bio-optical characteristics of the Western Arctic Ocean: Implications for ocean color algorithms, Can. J. Remote Sen., 33, 503518, 2007.

McClleland, J. W., Dery, S. J., Peterson, B. J., Holmes, R. M., and Wood, E. F.: A pan-arctic evaluation of changes in river discharge during the latter half of the 20th century, Geophys. Res. Lettr., 33, L06715, doi:10.1029/2006GL025753, 2006.

Miller, W. L. and Moran, M. A.: Interaction of photochemical and microbial processes in the degradation of refractory dissolved organic matter from a coastal marine environment, Limnol. Oceanogr., 42, 1317-1324, 1997.

Miller, W. L. and Zepp, R. G.: Photochemical production of dissolved inorganic carbon from terrestrial organic matter: significance to the oceanic organic carbon cycle, Geophys. Res. Lett., 22, 417-420, 1995.

Miller, W. L., Moran, M. A., Sheldon, W. M., Zepp, R. G., and Opsahl, S.: Determination of apparent quantum yield spectra for the formation of biologically labile photoproducts, Limnol. Oceanogr., 47, 343-352, 2002.

Moran, M. A. and Zepp, R. G.: Role of photoreactions in the formation of biologically labile compounds from dissolved organic matter, Limnol. Oceanogr., 42, 1307-1316, 1997.

Moran, M. A., Sheldon Jr, W. M., and Zepp, R. G.: Carbon loss and optical property changes during long-term photochemical and biological degradation of estuarine dissolved organic matter, Limnol. Oceanogr., 45, 1254-1264, 2000.

Nelson, N. B. and Siegel, D. A.: Chromophoric DOM in the Open Ocean, in: Biogeochemistry of marine dissolved organic matter, edited by: Hansell D. A. and Carlson C. A., Academic press, San Diego, 2002.

Nieke, B., Reuter, R., Heuermann, R., Wang, H., Babin, M., and Therriault, J. C.: Light absorption and fluorescence properties of chromophoric dissolved organic matter (CDOM), in the St. Lawrence Estuary (Case 2 waters), Cont. Shelf Res., 17, 235252, 1997.

Opsahl, S., Benner, R., and Amon, R. W.: Major flux of terrigenous dissolved organic matter through the Arctic Ocean, Limnol. Oceanogr., 44, 2017-2023, 1999.

Pegau, W. S., Gray, D., and Zaneveld, J. R. V.: Absorption and attenuation of visible and near-infrared light in water: dependence on temperature and salinity, Appl. Opt., 36, 6035-6046, 1997.
Peterson, B. J., R, Holmes, M., McClelland, J. W., Vorosmarty, C. J., Lammers, R. B., Shiklomanov, A. I., Shiklomanov, I. A., and Rahmstorf, S.: Increasing river discharge to the Arctic Ocean, Science, 298, 2171-2173, 2002.

Raymond, P.A., McClelland, J. W., Holmes, R. M., Zhulidov, A. V., Mull, K., Peterson, B. J., Striegl, R. G., Aiken, G. R., and Gurtovaya, T. Y.: Flux and age of dissolved organic carbon exported to the Arctic Ocean: A carbon isotopic study of the five largest arctic rivers, Global. Biogeochem. Cycles., 21, GB4011, doi:10.1029/2007GB002934, 2007.

Retamal, L., Vincent, W. F., Martineau, C., and Osburn, C. L.: Comparison of the optical properties of dissolved organic matter in two river-influenced coastal regions of the Canadian Arctic, Estuar. Coast. Shelf Sci., 72, 261-272, 2007.

Schauer, U. Muench, R. D., Rudels, B., and Timokhov, L.: Impact of eastern Arctic shelf waters on he Nansen Basin intermediate layers, J. Geophys. Res., 102, 3371-3382, 1997.

Shimada, K., Carmack, E. C., Hatakeyama, K., and Takizawa, T.: Varieties of Shallow Temperature Maximum Waters in the Western Canadian Basin of the Arctic Ocean, Geophys. Res. Lettr., 28(18), 3441-3444, 2001.

Shimada, K., Itoh, M., Nishino, S., McLaughlin, F., Carmack, E., and Proshutinsky, A.: Halocline structure in the Canada Basin of the Arctic Ocean, Geophys. Res. Lett., 32, L03605, doi:10.1029/2004GL021358, 2005.

Shimada, K., Kamoshida, T., Itoh, M., Nishino, S., Carmack, E., McLaughlin, F., Zimmermann, S., and Proshutinsky, A. Pacific Ocean inflow: Influence on catastrophic reduction of sea ice cover in the Arctic Ocean, Geophys. Res. Lett., 33, doi:10.1029/2005GL025624, 2006.

Sohrin, R., and Sempéré, R.: Seasonal variation in total organic carbon in the northeast Atlantic in 2000-2001, J. Geophys. Res., 110, C10S90, doi:10.1029/2004JC002731, 2005.

Stroeve, J., Serreze, M., Drobot, S., Gearheard, S., Holland, M. , Maslanik, J., Meier, W., and Scambos, T.: Arctic sea ice extent plummets in 2008, EOS Trans., AGU, 89(2), 13-14, 2008.

Tremblay, J.-É., Simpson, K., Martin, J. Miller, L. Gratton, Y., Barbar, D., and Price, N. M.: Vertical stability and the annual dynamics of nutrients and chlorophyll fluorescence in the coastal, southern Beaufort Sea, J. Geophys. Res., 113, C07S90, doi:10.1029/2007JC004547, 2008.

Twardowski, M., and Donaghay, P. L.: Photobleaching of aquatic dissolved materials: Absorption removal, spectral alteration, and their interrelationship, J. Geophys. Res., 107, doi:10.1029/1999JC000281, 2002.

Vodacek, A., Blough, N. V., DeGranpre, M. D., Peltzer, E. T., and Nelson, R. K.: Seasonal variations of CDOM and DOC in the Middle Atlantic Bight: Terrestrial inputs and photooxidation, Limnol. Oceanogr., 42, 674-686, 1997.

Winsor, P., and Chapman, D. C.: Distribution and interannual variability of dense water production from coastal polynyas on the Chukchi Shelf, J. Geophys. Res., 107(C7), 3079, doi:10.1029/2001JC000984, 2002.

Xie, H. and Gosselin, M.: Photoproduction of carbon monoxide in first-year sea ice in Franklin Bay, southeastern Beaufort Sea, Geophys. Res. Lett., 32, L12606, doi:10.1029/2005GL022803, 2005. 
A. Matsuoka et al.: Tracing CDOM for Arctic waters

Xie, H., Bélanger, S., Demers, S., Vincent, W. F., and Papakyriakou, T. N.: Photobiogeochemical cycling of carbon monoxide in the southern Beaufort Sea in spring and autumn, Limonl. Oceanogr., 54, 234-249, 2009.
Zepp, R. G., Sheldon, W. M., and Moran, M. Ann.: Dissolved organic fluorophores in southeastern US coastal waters: correction method for eliminating Rayleigh and Raman scattering peaks in excitation-emission matrices, Mar. Chem., 89, 15-36, 2004. 